\title{
Assessment and quantification of marginal lands for biomass production in Europe using soil-quality indicators
}

\author{
Werner Gerwin ${ }^{1}$, Frank Repmann ${ }^{2}$, Spyridon Galatsidas ${ }^{3}$, Despoina Vlachaki ${ }^{3}$, Nikos Gounaris ${ }^{3}$, \\ Wibke Baumgarten ${ }^{4}$, Christiane Volkmann ${ }^{4}$, Dimitrios Keramitzis $^{5}$, Fotis Kiourtsis ${ }^{5}$, and Dirk Freese ${ }^{2}$ \\ ${ }^{1}$ Research Center Landscape Development and Mining Landscapes, Brandenburg University \\ of Technology Cottbus-Senftenberg, 03046 Cottbus, Germany \\ ${ }^{2}$ Chair of Soil Protection and Recultivation, Brandenburg University of Technology \\ Cottbus-Senftenberg, 03046 Cottbus, Germany \\ ${ }^{3}$ Department of Forestry and Management of the Environment and Natural Resources, \\ Democritus University of Thrace, Orestiada, 68200, Greece \\ ${ }^{4}$ Fachagentur Nachwachsende Rohstoffe, 18276 Gülzow, Germany \\ ${ }^{5}$ Decentralized Administration of Macedonia \& Thrace, Thessaloniki, 54655, Greece
}

Correspondence: Werner Gerwin (werner.gerwin@b-tu.de)

Received: 15 May 2018 - Discussion started: 29 May 2018

Revised: 8 November 2018 - Accepted: 24 November 2018 - Published: 6 December 2018

\begin{abstract}
The cultivation of bioenergy plants in fertile, arable lands increasingly results in new land use conflicts with food production and cannot be considered as sustainable. Marginal lands have been frequently considered as potential alternatives for producing bioenergy from biomass. However, clear definitions and assessment methods for selecting marginal lands and for calculating potentials are still widely missing.

The project "SEEMLA" aims at triggering the exploitation of currently underused marginal lands for biomass production for energy purposes. Study sites have been selected in different European countries: Germany, Greece, and Ukraine. The selected sites represent a wide variety of different types of marginal lands. Based on a soil assessment set given by the Muencheberg Soil Quality Rating (SQR) system potentially "marginal" sites have been investigated. The SQR system allows for clearly distinguishing between soils of higher and lower quality. Soils with SQR scores below 40 are regarded as "marginal". They can be classified into different groups with regard to the importance of soil hazard indicators as evaluated by the SQR approach. The calculated SQR scores correlate significantly with biomass yields of bioenergy plants.

Further, the SQR method was adapted for use in a GIS study on marginal-land potentials in Europe. Thus, $46 \%$ of the investigated European area could be classified as "marginal" with SQR scores below 40. From that area $22.6 \%$ can be considered as potentially suitable for producing renewable resources after eliminating protected sites or other places not suitable for any kind of land use. Taking the ecological demands of selected bioenergy plants into account it is possible to give first preliminary recommendations for regional crop cultivation.

It can be concluded that Europe offers a large potential for renewable resources from marginal sites. However, the implementation into practice is often impeded by missing or varying policies and regulations. A proper implementation needs clear regulations and also incentives for farmers at the European level.
\end{abstract}




\section{Introduction}

With an increasing competition between traditional agriculture for food and feed production and production of renewable resources for bioenergy or biomaterials, both unconventional land use systems as well as use unconventional land gain more and more attention in Europe but also worldwide (Fischer et al., 2009; Popp et al., 2014; Rathmann et al., 2010). As part of a potential solution for this land use conflict, the utilization of lands which are not suitable for conventional high-productivity agriculture increasingly comes into focus. Such lands are frequently addressed as "marginal land" or "surplus land" in recent scientific publications (e.g. Dauber et al., 2012; Kang et al, 2013; Krasuska et al., 2010). However, these terms stand for a large group of very different types of land and definitions for marginal lands are, therefore, very diverse. Several terms are in use, with often synonymous meanings, such as "fallow", "set-aside", "abandoned", "degraded", or "waste land" (Dauber et al., 2012). Shortall (2013) distinguishes between "land unsuitable for food production", "ambiguous lower quality land" and "economically marginal land". This approach addresses the causes of marginality more explicitly which are also not uniform. They can be the result of land use changes due to technological or socio-economic transitions (Strijker, 2005) or related with poor natural prerequisites for agriculture. The latter is mainly connected with soil-inherent site properties which limit the productivity of crop production.

With respect to policies and legal framework, i.e. Common Agricultural Policy (CAP; EC, 2013b), a definition of marginality of land and its use in agriculture and/or forestry is not given. However, both on the member state and EU level, an assessment of land quality and its proper, sustainable, economic, and efficient use is needed, especially with respect to feedstock production in marginal or abandoned land, and also considering incentive opportunities which have to be tailored for and adapted to in the already established policy framework.

Results of assessing potentials of marginal lands suitable for bioenergy production vary widely. As a rough estimation Wolf et al. (2003) stated that about $65 \%$ of the global land area that is potentially suitable for agriculture could contribute to purposes like biomass production. However, this area would be halved if only the presently used arable lands are considered and other functions of land are taken into account, e.g. nature conservation. Particularly, sites which can be classified as "marginal" offer potentials for biodiversity protection and their use might generate new conflicts, e.g. with nature conservation (Dauber and Miyake, 2016; Miyake et al., 2015; Plieninger and Gaertner, 2011).

A careful assessment is needed, therefore, for a proper estimation of potentials of marginal sites for future biomass supply. Different numbers have been reported during the last few years in this regard. Krasuska et al. (2010) mentioned a total area available for non-food crops in the European Union of up to 13.2 Mha. According to this study most of this land is allocated in eastern Europe. For Canada, Liu et al. (2017) calculated a sum of $9.5 \mathrm{Mha}$ of available marginal lands mainly in the southern part of the country. This latter assumption was based on a soil-related approach using the Canadian Land Inventory soil capability classes of the Land Suitability Rating System (LSRS; Agronomic Interpretations Working Group, 1995) as indicators of marginality.

Soil rating systems have been developed in several regions and for different purposes. In Germany, the official land appraisal system ("Bodenschätzung") was developed in the 1930s to estimate the fiscal value of arable lands and pastures. This methodology is based on a rough estimation of the "average" soil texture of the profile ( $1 \mathrm{~m}$ depth). Data are available nationwide but the transfer of these data to modern scientific soil approaches turns out to be difficult (Hangen and Förster, 2013; Mueller et al., 2010). FAO officially provides the Visual Soil Assessment (VSA) system originally developed by Shepherd (2000). More recently, and partly based on the VSA approach, the Soil Quality Rating system (SQR) was elaborated by Mueller et al. (2007). This system was developed as a field guide for assessing soil quality with regard to agricultural crop production using up-to-date scientific soil methods. The indicators used in this approach are similar to the biophysical criteria which were suggested to describe and define natural constraints for agriculture in Europe (van Orshoven et al., 2014), and which are used by the EU Commission for designating areas facing natural and other specific constraints for agriculture (ANCs; EU regulation No 1305/2013; EC, 2013a). The great advantage of the SQR methodology is that soil quality as a function of a comprehensive set of indicators is expressed in one single number and therefore easy to evaluate. For that reason, the SQR system was taken as the basis for an overall estimation and mapping of agricultural yield potentials in Germany carried out by the German Federal Institute for Geosciences and Natural Resources (BGR, 2013).

Mapping of marginal lands has been frequently carried out for different regions and scales as well as with different methodological approaches (e.g. Breuning-Madsen et al., 1990; Cai et al., 2011). In this paper an approach is introduced for assessing and quantifying the area of marginal lands available in Europe for bioenergy production. The presented study is part of the project "Sustainable exploitation of biomass for bioenergy from marginal lands in Europe (SEEMLA)", which aims at triggering the exploitation of currently underused marginal lands for biomass production for energy purposes. One of the project tasks is the identification of suitable marginal lands as alternative production sites taking into account possible conflicts with competing land use strategies, e.g. food production or nature conservation.

The SEEMLA approach presented in this paper is thought to contribute to the methodological development of assessment tools needed for step 1 (estimation of biomass tech- 
nical potentials) of the analytical framework for evaluating sustainable biomass production potentials as proposed in a review by Batidzirai et al. (2012). Previous studies on global or European bioenergy potentials often tried to assess land availability for future bioenergy production mainly based on land use data and detectable changes derived by means of remote-sensing methods (e.g. Campbell et al., 2008; Krasuska et al., 2010). However, Fritz et al. (2013) as well as Nalepa and Bauer (2012) demonstrated shortcomings of such approaches due to scaling problems. The approach presented here is based on an assessment of soil quality and related agricultural yield potentials using the SQR methodology. Results can reach a high spatial resolution depending on the availability and quality of input data. For Germany it had been demonstrated that high-precision mapping of soil quality and related agricultural yield potentials is feasible (BGR, 2013). Additionally, this SEEMLA approach is supposed to allow for a clear differentiation between fertile agricultural lands and marginal lands with poor soil quality and weak agricultural yield potentials which are considered to be still appropriate for bioenergy production. The SQR methodology explicitly includes numerous indicators for site-related hazards for agricultural land use so that physicochemical constraints of marginal lands and their severity can be directly revealed as demanded by Batidzirai et al. (2012).

In this regard the objectives of this study are (i) to identify and test a suitable methodology for discriminating marginal lands, (ii) to characterize and classify marginal lands from a soil-related perspective, and (iii) to apply the methodology for a Europe-wide assessment of marginal-land potentials for bioenergy production. For that purpose, the SQR system was applied and tested to provide soil-related indicators of marginality which can be used for mapping marginal lands in Europe. It was assumed that marginal sites are characterized by low soil fertility or quality as expressed by low or very low $\mathrm{SQR}$ scores. It was further assumed that productivity of such sites is clearly limited for traditional agriculture by means of lacking soil quality so that the mentioned competition between both land use strategies could be mitigated if bioenergy is produced here.

For testing these assumptions soils of marginal sites selected in different European countries were analysed and assessed according to the SQR methodology. These investigations were thought to confirm the general applicability of the SQR framework for non-agricultural sites and for bioenergy crops as well. Further, the main limiting factors for the selected marginal-land types were evaluated. In a second step a continent-wide mapping of potential areas for bioenergy production was carried out by means of the SQR methodology adapted according to BGR (2010). The objective was to assess both the overall area of land with low and very low SQR scores and the area of land available without further land use conflicts by excluding protected areas. Finally, recommendations for overcoming further existing policy and legislative constrains are given as an outlook.

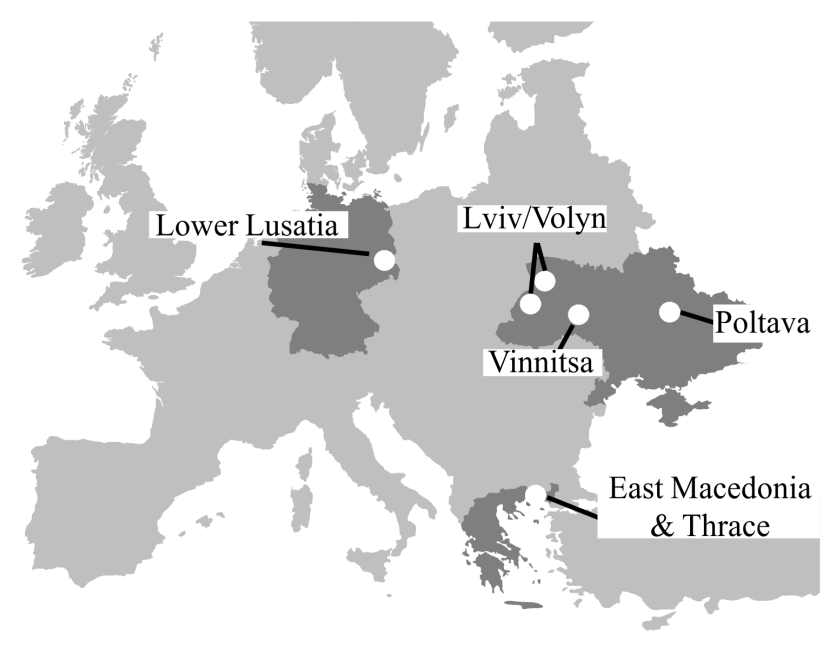

Figure 1. European regions with investigated case study sites.

\section{Material and methods}

\subsection{Assessing marginality at case study sites}

\subsubsection{Case study sites}

Case study sites were chosen across three European countries for investigating and demonstrating the practical applicability of bioenergy production on marginal lands. The selection was made to represent different types of marginal lands and different types of climate regimes (Fig. 1 and Table 1). At these sites different methods of bioenergy production were implemented as case studies. At each site soil profiles were analysed, soil samples were taken, and soil assessment according to the SQR framework was carried out.

Most of the Ukrainian sites and all investigated Greek sites show limitations for traditional agriculture due to natural constraints and in part due to anthropogenic degradation. The sites in the western part of Ukraine (Volyn and Lviv regions) and in the Poltava region represent the type of abandoned land which was formerly used for conventional agriculture and set aside due to different site-specific reasons. In Greece sites with naturally poor soil conditions (e.g. shallow soil depth) were selected in a mountainous region (Rhodope Mountains). The sites are currently in use for forestry or in some parts for low-intensity pasture systems.

In contrast, the Vinnitsa site in Ukraine as well as the two German sites has undergone the most severe anthropogenic disturbances. The Vinnitsa site was used as a municipal waste dump before; waste has been removed before preparing the site. In Lusatia (State of Brandenburg, eastern Germany) post-mining sites and former industrial or traffic areas represent types of marginal lands which can be frequently found particularly in central and eastern Europe.

With regard to climatic conditions (cf. Table 1) the selected field sites are within two gradients: (a) between subcontinental and continental and (b) between temperate and 
Table 1. Overview of investigated case study sites: locations, climatic conditions, and cultivated bioenergy crops.

\begin{tabular}{|c|c|c|c|c|c|}
\hline Region & $\begin{array}{l}\text { Local name } \\
\text { (village/ } \\
\text { town) }\end{array}$ & $\begin{array}{l}\text { Site and } \\
\text { profile } \\
\text { numbers }\end{array}$ & $\begin{array}{l}\text { Mean annual } \\
\text { temperature/ } \\
\text { precipitation }\end{array}$ & $\begin{array}{l}\text { De Martonne } \\
\text { Aridity Index }\end{array}$ & $\begin{array}{l}\text { Type of bioenergy } \\
\text { production } \\
\text { planned }\end{array}$ \\
\hline \multicolumn{6}{|c|}{ Ukraine } \\
\hline Vinnitsa & Yaltushky & $\begin{array}{l}\text { UA Vin } 1 \\
\text { UA Vin } 2\end{array}$ & $6.9^{\circ} \mathrm{C} / 529 \mathrm{~mm}$ & 28.5 & $\begin{array}{l}\text { Perennial bioenergy crops } \\
\text { (Miscanthus } \times \text { giganteus, }\end{array}$ \\
\hline Poltava & Semeniwka & $\begin{array}{l}\text { UA Pol } 1 \\
\text { UA Pol } 2\end{array}$ & $7.7^{\circ} \mathrm{C} / 511 \mathrm{~mm}$ & 33.0 & $\begin{array}{l}\text { Panicum virgantum)/energy } \\
\text { trees (Salix sp.) }\end{array}$ \\
\hline Volyn & Zubylne/Kysylyn & $\begin{array}{l}\text { UA Vol A } \\
\text { UA Vol B } \\
\text { UA Vol C }\end{array}$ & $9.5^{\circ} \mathrm{C} / 610 \mathrm{~mm}$ & 31.1 & $\begin{array}{l}\text { Energy trees (Salix spec., } \\
\text { Populus sp.) }\end{array}$ \\
\hline Lviv & Welyki Mosty & $\begin{array}{l}\text { UA Lvi A } \\
\text { UA Lvi B } \\
\text { UA Lvi C } \\
\text { UA Lvi D }\end{array}$ & $6.9^{\circ} \mathrm{C} / 668 \mathrm{~mm}$ & 37.7 & \\
\hline \multicolumn{6}{|c|}{ Greece } \\
\hline $\begin{array}{l}\text { East Macedonia } \\
\& \text { Thrace }\end{array}$ & $\begin{array}{l}\text { Sarakini } \\
\text { Drosia } \\
\text { Pelagia }\end{array}$ & $\begin{array}{l}\text { GR Sara } 1 \\
\text { GR Dro } 1 \\
\text { GR Dro } 2 \\
\text { GR Pel } 1 \\
\text { GR Pel } 2\end{array}$ & $14.8^{\circ} \mathrm{C} / 672 \mathrm{~mm}$ & 16.8 & $\begin{array}{l}\text { Energy trees (Pinus sp., } \\
\text { Robinia pseudoacacia) }\end{array}$ \\
\hline \multicolumn{6}{|c|}{ Germany } \\
\hline $\begin{array}{l}\text { Lower } \\
\text { Lusatia } \\
\text { (State of } \\
\text { Brandenburg) }\end{array}$ & $\begin{array}{l}\text { Welzow } \\
\text { Cottbus }\end{array}$ & $\begin{array}{l}\text { DE Wel } 1 \\
\text { DE Wel } 2 \\
\text { DE DB } 1 \\
\text { DE DB } 2\end{array}$ & $8.9^{\circ} \mathrm{C} / 563 \mathrm{~mm}$ & 32.1 & $\begin{array}{l}\text { Energy trees (Robinia } \\
\text { pseudoacacia, } \\
\text { Populus sp.) }\end{array}$ \\
\hline
\end{tabular}

Mediterranean types of climate. The Ukrainian sites are characterized by continental climate conditions, whereas Lower Lusatia in eastern Germany has a subcontinentally influenced climate of the temperate zone. Northern Greece is part of the Mediterranean climate region with semiarid climatic conditions.

\subsubsection{Soil-quality assessment: SQR rating system}

To assess soil quality (or conversely marginality) the Muencheberg Soil Quality Rating system (SQR; Mueller et al., 2007) was applied using the soil parameters derived from field and laboratory measurements. The SQR is designed to quantify the soil quality by a single value - theoretically ranging from 1 to 100 points - which is calculated on the basis of a set of basic and hazard indicators.

One set of eight basic indicators describes generic soil parameters (B 1: substrate, B 2: A horizon depth, B 3: topsoil structure, B 4: subsoil compaction, B 5: rooting depth, B 6: profile available water, B 7: wetness and ponding, B 8: slope and relief). Single scores are summarized and the resulting basic score has a range between 0 and 34 for arable land. Whereas 0 stands for absolutely infertile soils, 34 can be reached by best suited croplands. In a second step, 13 hazard indicators are examined including further factors influencing soil conditions and ecological functions (H 1: contamination, H 2: salinization, H 3: sodification, H 4: acidification, H 5: low total nutrient status, H 6: soil depth above hard rock, H 7: drought, H 8: flooding or extreme waterlogging, H 9: steep slope, $\mathbf{H}$ 10: rock at the surface, $\mathbf{H}$ 11: high percentage of coarse soil texture fragments, $\mathbf{H}$ 12: unsuitable soil thermal regime, H 13: miscellaneous hazards). For each hazard indicator the SQR guidelines provide multipliers on a ratio scale between 0.1 and 3. The lowest multiplier found (i.e. the most important hazard for the respective site) is used to calculate the final SQR score which is within a range between 0 and 100. Sites with a final score of 100 can be seen as sites with the best suitable soils for agriculture, whereas soils with SQR scores $<40$ can be regarded as very poor or poor with regard to agricultural land use (Mueller et al., 2007). Such sites are classified here as "marginal".

\subsubsection{Soil profile description, soil sampling, and laboratory analyses}

Soil profiles were investigated at each case study site in summer 2016. Profile descriptions were carried out according to the methodology of the German soil classification sys- 
Table 2. Soil parameters assessed in the field and as basis for assessing SQR indicators.

\begin{tabular}{|c|c|c|}
\hline Parameter & Methodology & $\begin{array}{l}\text { SQR } \\
\text { indica- } \\
\text { tors }\end{array}$ \\
\hline Soil texture & $\begin{array}{l}\text { Particle size analysis after destruction of carbonates (application of } \mathrm{HCl} \text { ) and organic substances } \\
\text { (application of } \mathrm{H}_{2} \mathrm{O}_{2} \text { ), suspension with } \mathrm{Na}_{4} \mathrm{P}_{2} \mathrm{O}_{7} \text {, determination of sand fractions by sieving } \\
(<2-0.63,<0.63-0.2 \text {, and }<0.2-0.063 \mathrm{~mm} \text {, determination of silt and clay by sedimentation } \\
\text { analysis according to Köhn (Blume et al., 2011). }\end{array}$ & B 1 \\
\hline Soil depth & Measurement (soil profile: A horizon, depth of hard rock) & $\begin{array}{l}\text { B } 2, \\
\text { H } 6\end{array}$ \\
\hline Soil structure & $\begin{array}{l}\text { Visual assessment according to Lists 19-22 of the German Soil Mapping Guidelines (AG Bo- } \\
\text { den, 2005) }\end{array}$ & B 3 \\
\hline Bulk density & $\begin{array}{l}\text { Weighing volumetric soil samples (volume of sampling rings: } 100 \mathrm{~cm}^{3} \text { ) after drying (Blume et } \\
\text { al., 2011), converted into packing density values according to Harrach et al. (1999) }\end{array}$ & B 4 \\
\hline Rooting depth & $\begin{array}{l}\text { Effective rooting depth assessed according to Table } 81 \text { of German Soil Mapping Guidelines } \\
\text { (AG Boden, 2005) }\end{array}$ & B 5 \\
\hline $\begin{array}{l}\text { Profile avail- } \\
\text { able water }\end{array}$ & $\begin{array}{l}\text { Assessment of plant available field capacity according to Table } 70 \text { of German Soil Mapping } \\
\text { Guidelines (AG Boden, 2005), water volume calculated for the effective rooting depth }\end{array}$ & B 6 \\
\hline $\begin{array}{l}\text { Hydromorphic } \\
\text { features }\end{array}$ & $\begin{array}{l}\text { Visual inspection of profile and soil colours (occurrence of mottles, rusty or pale colours, dark } \\
\text { concretions, etc.) }\end{array}$ & B 7 \\
\hline Relief situation & $\begin{array}{l}\text { Assessment of slope inclination according to Table } 6 \text { of German Soil Mapping Guidelines } \\
\text { (AG Boden, 2005) }\end{array}$ & $\begin{array}{l}\text { B } 8, \\
\text { H } 9\end{array}$ \\
\hline $\begin{array}{l}\text { Element con- } \\
\text { tent (heavy } \\
\text { metals) }\end{array}$ & $\begin{array}{l}\text { Measurement in solid soil samples using an x-ray fluorescence device (NITON XL3t analyser, } \\
\text { Thermo Fisher) }\end{array}$ & H 1 \\
\hline $\mathrm{EC}_{2.5}$ & $\begin{array}{l}\text { Measurement in } 1: 2.5 \text { soil : water suspension (Blume et al., 2011), conversion into } \text { EC }_{\text {SE }} \text { values } \\
\text { according to FAO (2006) }\end{array}$ & $\mathrm{H} 2$ \\
\hline $\mathrm{pH}_{\mathrm{H}_{2} \mathrm{O}}$ & Measurement in $1: 2.5$ soil : water suspension (Blume et al., 2011). & $\begin{array}{l}\mathrm{H} 3 \\
\mathrm{H}\end{array}$ \\
\hline $\begin{array}{l}\text { Plant available } \\
\text { nutrients }(\mathrm{P}, \mathrm{K})\end{array}$ & Measurement in solutions from lactate extraction (Blume et al., 2011) using ICP OES & H 5 \\
\hline $\begin{array}{l}\text { Coarse frag- } \\
\text { ments }\end{array}$ & Sieving of substrate $(>2 \mathrm{~mm})$ from the surface and the soil profile & $\begin{array}{l}\text { H } 10, \\
\text { H } 11\end{array}$ \\
\hline Climate & $\begin{array}{l}\text { Analysis of climate data provided for each site: calculation of De Martonne Aridity Index } \\
\text { (Mueller et al., 2007) and of duration of frost free period }\end{array}$ & $\begin{array}{l}\text { H } 7, \\
\text { H } 12\end{array}$ \\
\hline Ponding & Visual inspection of the site: indications of waterlogging at the surface & H 8 \\
\hline
\end{tabular}

tem (AG Boden, 2005). The soil horizon designations were transferred to international symbols according to Blume et al. (2016). Soil types were classified according to international standards provided by the World Reference Base for Soil Resources (WRB; IUSS Working Group WRB, 2007). Soil samples were taken from dominant soil horizons directly from the profile. From the selected horizons volumetric samples were taken by means of sampling rings for determining bulk density. In addition, mixed samples were taken from different depths at the study sites with different borers (depending on site conditions) and merged. Mixed soil samples were dried $\left(3\right.$ days at $\left.40^{\circ} \mathrm{C}\right)$ and sieved $(<2 \mathrm{~mm})$. Table 2 gives an overview of parameters assessed by means of field and laboratory methods as needed for soil assessment (SQR). According to the SQR method, hints for contaminations, particularly signs of artefact colour or odour, can be roughly tested by means of sensory analysis (Lichtfuss, 2004). Suspicious colours or odour that could indicate possible contamination with organic compounds were not detectable within any of the investigated soil profiles, so that further analysis in the laboratory was restricted to possible inorganic contamination with heavy metals. Measured values of relevant parameters are available from Table A1 (Appendix A).

\subsubsection{Soil-quality assessment and biomass yield estimation}

For testing the suitability of SQR scores for bioenergy crops mean biomass data were collected for all case study regions. As plantations with bioenergy crops were established at all investigated case study sites later on, direct correlations between field-specific SQR scores and biomass yields could not be investigated yet. Thus, regional project partners provided data on average biomass yields from adjacent field sites with soil conditions comparable to the respective case study sites. These data for the same bioenergy crops as cultivated on the 


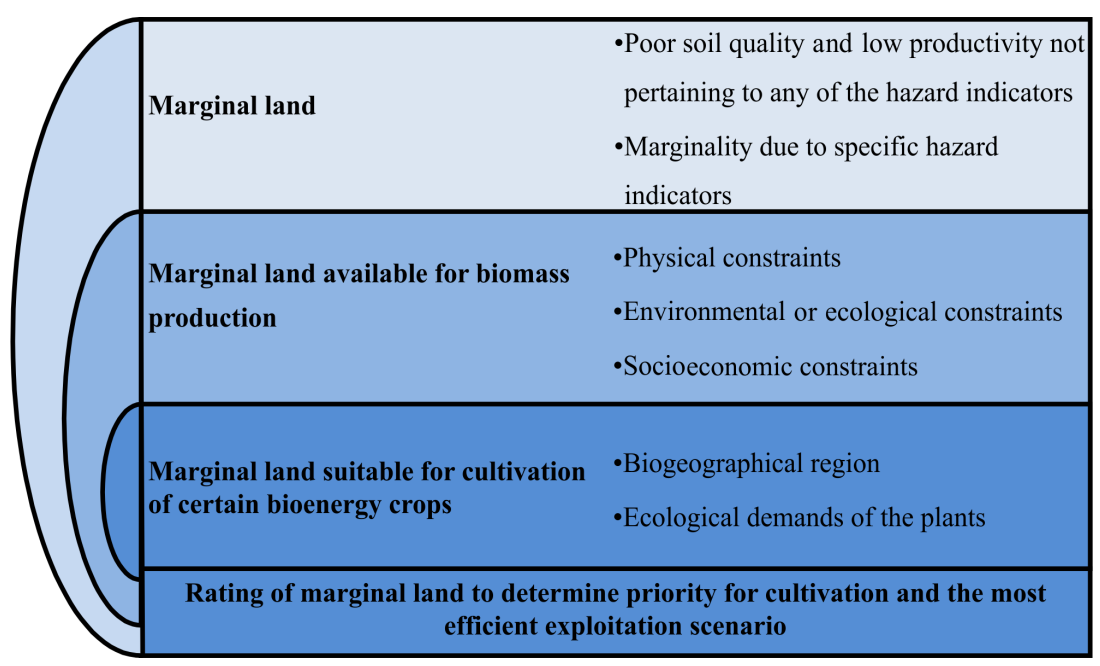

Figure 2. SEEMLA algorithm.

case study sites were used as an estimate of local biomass yields. The available biomass yield data were roughly separated into two groups: biomass yields from woody bioenergy crops (willow, poplar, black locust, and pine) and from grasslike species (miscanthus, switchgrass). The non-parametric Spearman rank coefficient between SQR final scores and mean biomass yields from woody bioenergy crops $(n=16)$ was calculated and tested for significance using the R statistical package (R Commander). The small dataset for grass-like bioenergy crops $(n=4)$ did not allow for calculating correlation coefficients.

\subsubsection{Data processing and statistical analysis}

SQR score calculations and correlation statistics were performed using MS Excel statistical functions. For deriving typical sets of soil constraints for different types of marginal lands, the investigated sites were grouped according to the relevance of their assigned SQR hazard indicators. For this purpose, the assessed SQR hazard multipliers with values between 0.1 (highest influence of this hazard indicator) and 3 (no influence of this hazard indicator) were transformed to a scale of influence (values ranging between 1.0 - hazard of highest relevance for a site - and 0 - no hazard influence detectable). These influence values for the individual hazard indicators were calculated following Eq. (1):

Influence $=1-\frac{x}{3}$

with $x$ is equal to value of hazard indicator multipliers.

The resulting transformed values (as summarized in Table A2, Appendix A) were subject to a cluster analysis (Ward method, squared Euclidian distance) using R statistical package (R Commander). For each cluster, mean values of influence were calculated for all hazard indicators.

\subsection{Concept for quantifying marginal-land area in Europe}

\subsection{Analysis algorithm}

A new algorithm (SEEMLA algorithm) has been developed to characterize marginal lands mainly based on the SQR tool for assessing soil quality. The analysis algorithm investigates land marginality, marginal-land availability for biomass production for bioenergy purposes, and its suitability for specific bioenergy crops (Fig. 2). Geospatial analysis using a geographical information system (GIS) was applied to identify and display areas of marginal land in Europe.

Marginal land can be clearly defined, based on the scoring scheme of the SQR system. Lands with poor production potential are considered the ones scoring below 40 in the SQR system. Establishing the availability of marginal land for biomass production, however, requires the investigation of certain constraints that can be categorized into three types: physical land constraints (e.g. steep slope that hinders mechanization of works); environmental-ecological constraints (e.g. protected areas) and socio-economic constraints (e.g. distance to processing facility, current land use). Such generic criteria have been applied to exclude marginal lands under these constrains and localize areas available for biomass exploitation.

Information regarding the biogeographical region and the biological demands of selected crop species (Table 3) were used to screen the available marginal lands and identify which areas are appropriate for cultivation of the crop species (EUFORGEN, 2016; Korakis, 2015; PFAF, 2016; SanMiguel-Ayanz et al., 2016; Śliż-Szkliniarz, 2013; USDA, 2016). This process cross-references site parameters with the biological demands of the crop species to determine lands suitable for cultivation of certain bioenergy crops. 
Table 3. Selected bioenergy crops screening criteria - specific growing conditions.

\begin{tabular}{|c|c|c|c|c|c|}
\hline $\begin{array}{l}\text { Common } \\
\text { name }\end{array}$ & $\begin{array}{l}\text { Scientific } \\
\text { name }\end{array}$ & $\begin{array}{l}\text { Climatic } \\
\text { zone }\end{array}$ & $\begin{array}{r}\text { Optimal altitude } \\
(\min -\max ) \\
(\mathrm{m} \text { a.s.1. })\end{array}$ & $\begin{array}{r}\text { Optimal soil pH } \\
(\min -\max )\end{array}$ & $\begin{array}{l}\text { Optimal soil } \\
\text { moisture } \\
\text { conditions }\end{array}$ \\
\hline Black locust & $\begin{array}{l}\text { Robinia } \\
\text { pseudoacacia }\end{array}$ & $\begin{array}{l}\text { Atlantic } \\
\text { Continental } \\
\text { Mediterranean }\end{array}$ & $0-1040 \mathrm{~m}$ & $4.5-8.2$ & well-drained \\
\hline Black pine & Pinus nigra & $\begin{array}{l}\text { Atlantic } \\
\text { Continental } \\
\text { Mediterranean }\end{array}$ & $350-2200 \mathrm{~m}$ & $4-8$ & dry \\
\hline Basket willow & Salix viminalis & $\begin{array}{l}\text { Atlantic } \\
\text { Continental }\end{array}$ & $0-570 \mathrm{~m}$ & $5-7.5$ & well-drained to wet \\
\hline Poplar & Populus sp. & $\begin{array}{l}\text { Atlantic } \\
\text { Continental } \\
\text { Mediterranean }\end{array}$ & $0-1200 \mathrm{~m}$ & $4.5-7.5$ & wet \\
\hline Miscanthus & $\begin{array}{l}\text { Miscanthus } \times \\
\text { giganteus }\end{array}$ & $\begin{array}{l}\text { Atlantic } \\
\text { Continental }\end{array}$ & $0-1000 \mathrm{~m}$ & $5.5-7.5$ & moist, well-drained \\
\hline Switchgrass & $\begin{array}{l}\text { Panicum } \\
\text { virgatum }\end{array}$ & $\begin{array}{l}\text { Atlantic } \\
\text { Continental } \\
\text { Mediterranean }\end{array}$ & $0-700 \mathrm{~m}$ & $5-7$ & moderate to well-drained \\
\hline
\end{tabular}

Table 4. Overview of geospatial datasets used and corresponding sources needed for SQR basic and hazard indicator valuation (B 1-8; H 1-13).

\begin{tabular}{|c|c|c|}
\hline Datasets & Extent & Data source \\
\hline Soil properties & European & ESDAC European Soil Database \\
\hline (B 1-B7, H 1-H 6, H 9, & Global & distribution v2.0 FAO Harmonized World \\
\hline H 11 and bioenergy crop demands) & & Soil Database (HWSD) v 1.2 \\
\hline Limitations to agricultural use $(\mathrm{H} 8, \mathrm{H} 10$, and $\mathrm{H} 13)$ & European & ESDAC European Soil Database distribution v2.0 \\
\hline Climate data (H 7) & Global & WorldClim - Global Climate Data \\
\hline $\begin{array}{l}\text { Köppen-Geiger Climate Classification } \\
\text { (H } 12 \text { \& bioenergy crop demands) }\end{array}$ & Global & Institute for Veterinary Public Health \\
\hline Slope (B 8, H 9) & Global & $\begin{array}{l}\text { NASA Shuttle Radar Topography Mission } \\
\text { (SRTM) digital elevation model }\end{array}$ \\
\hline Protected areas in Europe & European & European Environment Agency (EEA) \\
\hline Corine Land Cover v.18.5.1 & European & EEA Copernicus programme \\
\hline
\end{tabular}

\subsubsection{Geospatial datasets}

An extensive search was carried out in order to obtain geographical data for the algorithm components for European countries. The required geospatial datasets include the basic and hazard indicators for the calculation of the SQR score (Table 4), the screening criteria for the selection of bioenergy crops (Table 3), and additional information regarding protected areas and current land cover (Table 4).

Pan-European datasets of the European Soil Data Center (ESDAC) have been primarily used, whereas data from the HWSD were used for areas or parameters not covered by the ESDAC datasets, especially for Ukraine. The resolution of the original input datasets varied from $250 \mathrm{~m}$ to $5 \mathrm{~km}$. A uniform cell size of $500 \mathrm{~m}$ was applied to all datasets before the analysis. The resolution was selected following the resolution of the geospatial data available for soil texture classes from ESDAC. The selection was based on the fact that soil texture is itself one of the basic indicators for the calculation of SQR (B 1) and also a parameter for the calculation of two additional basic indicators (B $5 \&$ B 6). Thus, the application of its resolution was selected to reflect substrate variations across Europe. Resampling for discrete data (e.g. land use) was performed using the nearest resampling algorithm, whereas bilinear interpolation was applied for continuous data.

The coordinate reference system is ETRS89-LAEA Europe, EPSG:3035. Latitude of origin: $52^{\circ} \mathrm{N}$, longitude of origin (central meridian): $10^{\circ} \mathrm{E}$

Each raster dataset was reclassified based on the SQR field manual, the SQR assessment scheme according to BGR (2010), and adaptations made by Brandenburg Univer- 
sity of Technology Cottbus-Senftenberg within the SEEMLA project.

\subsubsection{Development of the GIS tool}

The SEEMLA algorithm was the basis for the development of a GIS toolset to quantify marginal land in Europe and evaluate its potential for biomass production for bioenergy through raster analysis. The necessary geospatial datasets were accordingly processed to allow for implementation of the appropriate SQR calculations and subsequent compilations.

Raster analysis was applied, after the datasets were reclassified in compliance with the SQR classes for basic and hazard indicators. The next step was to apply elimination criteria to derive the suitability of marginal lands for biomass production. The last function of the GIS toolset cross-references the site conditions with crop species demands to determine appropriate marginal lands for cultivating selected crop species.

The outputs of the GIS toolset can be used to produce various thematic maps such as SQR or marginal-land map for Europe, most important hazard indicator, marginal-land suitability per bioenergy crop, and any desired combination of the resulted layers.

The application was developed as a toolbox for ESRI ArcGIS desktop (v.10.2.2 or newer). The GIS outputs include both raster (cell size $500 \times 500 \mathrm{~m}$ ) and vector datasets and corresponding maps. The standardized outputs include the following information:

1. mapping and quantification of marginal lands in Europe using the Muencheberg SQR system,

2. mapping and quantification of marginal land available for biomass production for bioenergy,

3. mapping and quantification of marginal land suitable for cultivation of certain bioenergy crops,

4. mapping and quantification of hazard indicators per raster cell,

5. mapping and identification of the most important hazard indicator.

\section{Results and discussion}

\subsection{Soils of marginal lands}

Soil physical and chemical parameters needed for assessing the SQR indicators are available in Table A1 (Appendix A). In the western Ukrainian regions of Volyn and Lviv, sites have been investigated on former arable land which is not further used for agriculture for more than 20 years. The reasons for setting these areas aside are mainly of socio-economic nature but the studied soils also show clear obstacles for conventional agriculture. Most of the investigated sites are in a flat landscape, but some in a slightly hilly landscape with an altitude of about $200 \mathrm{~m}$ a.s.l. are characterized by sandy substrate and often high groundwater tables. Mires are developed in landscape depressions. With regard to soil types (WRB), both regions are very diverse (Fig. 3) with dominating Cambisols, Regosols, and Arenosols as well as Stagnosols. Final SQR scores are within a range from 18.0 to 37.1. The case study site close to Poltava is part of the Chernozem region in the central part of Ukraine. However, marginal lands can be frequently found in flat hollows with high groundwater tables which impede agricultural land use. Gleysols developed here with the frequent risk of flooding during spring time. SQR scores of such sites were determined between 55 for better conditions and 1.7 in an extreme situation (regularly completely flooded).

In the mountainous northern part of Greece different very shallow soil profiles have been investigated. In addition, these soils are characterized by a very stony texture and are located partly on steep slopes. Most probably the shallow profiles are the result of erosion processes which occurred previously during periods with a more intensive land use (deforestation, pasture). Today the sites are covered by forests or meadows. The altitude is between 100 and $590 \mathrm{~m}$ a.s.1. and the relief is mountainous. Soil types (WRB) found here can be classified as Leptosols or Regosols. The latter is also developed as Colluvic Regosols in small hollows or at the bottom of hillslopes (Fig. 3). Final SQR scores are between 7.6 and 19.3.

Anthropogenic degradation processes were responsible for the formation of soils investigated at the German post-mining and post-industrial sites. Their soils are characterized by the lack of organic matter and the initially still missing soil structure. Furthermore, they often contain mixed-in lignite particles, technogenic material, and other coarse substrates like rubble from demolished buildings. At the former waste dump site in the Vinnitsa region of Ukraine several remaining waste particles were still present in the upper part of the soil profile. Frequent soil types (WRB) found in such anthropogenic sites are Regosols or Technosols, both in post-mining landscapes (Spolic Technosols) and in post-industrial sites (Urbic Technosols) (Fig. 2) and SQR scores vary between 9.1 (postindustrial site) and 29 (Vinnitsa waste dump site).

\subsection{Assessing marginality}

\subsubsection{Results of SQR soil-quality assessment}

The SQR assessment of soil quality clearly shows that most of the selected marginal-land sites can be in fact considered as "poor" or even "very poor". With only one exception (abandoned arable land in Poltava region, Ukraine: SQR value: 55.0) all final SQR scores are below the threshold of 40 (Fig. 4). The mean basic score is 17.1 indicating medium 
(a)

(d)
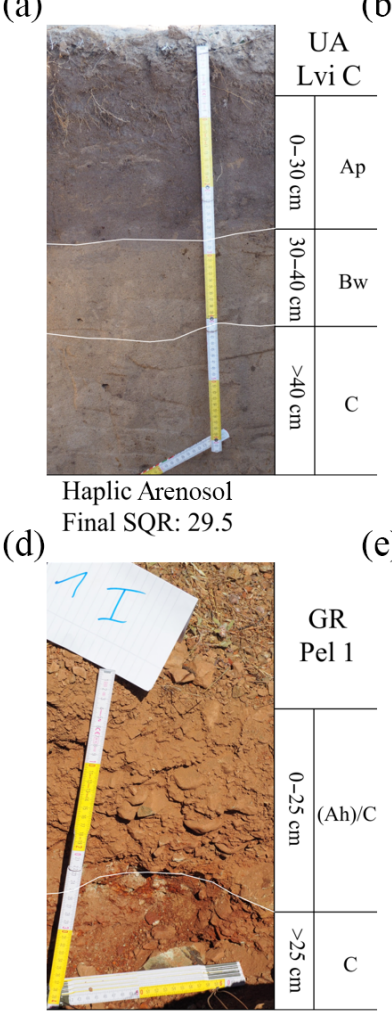

(g)

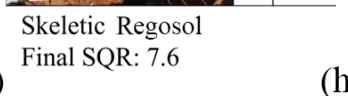

(e) (b)
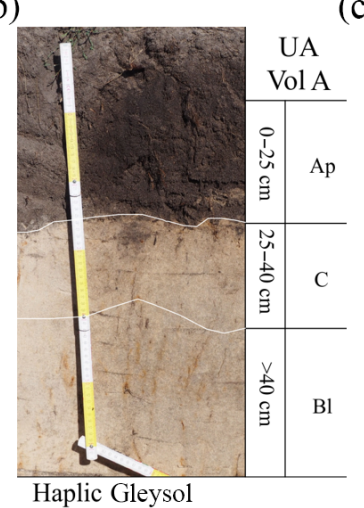
Final SQR: 37.1

)

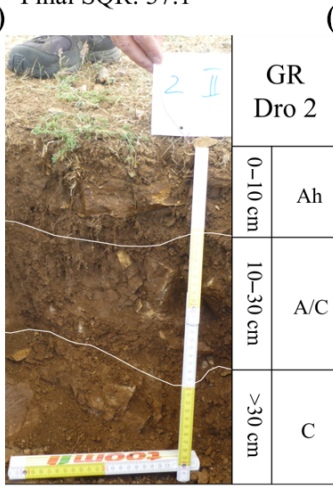

(h)

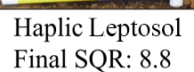

Final SQR: 8.8 (c)

(i)

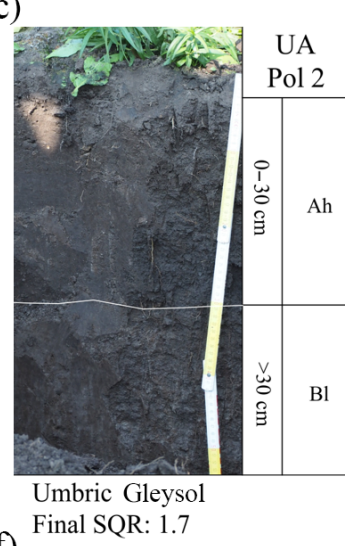

(f)
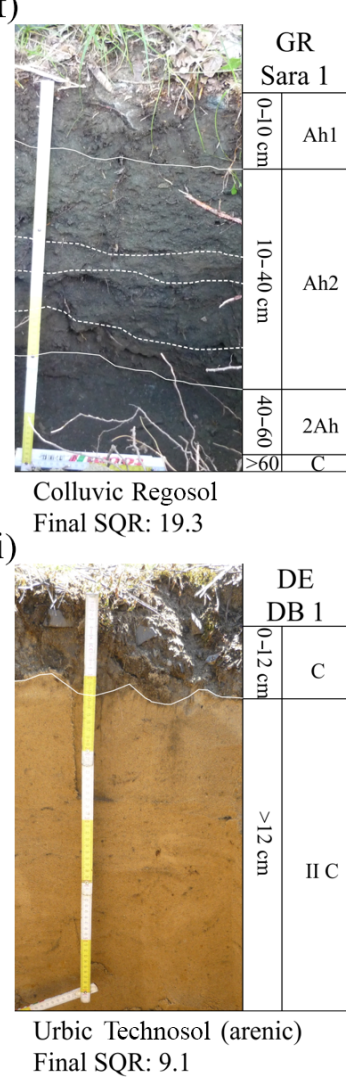

Figure 3. Soil profiles of marginal lands: (a, b, c) abandoned arable lands in Ukraine (UA); (d, e, f) mountain soil profiles in Greece (GR); $(\mathbf{g}, \mathbf{h}, \mathbf{i})$ anthropogenically degraded soils in Ukraine (UA) and Germany (DE).

soil conditions in general and the mean final SQR score of 22.5 clearly reveals the low quality of soils of marginal lands. For comparison, a mean SQR score of 64 for arable land in Germany was determined by Hennings et al. (2016). In general, the SQR methodology seems be a generally applicable technique for identifying marginal lands based on soil parameters.

The post-industrial sites (former railway sites, Germany) reached the lowest basic score values as a result of a weak natural potential of the prevailing artificially created substrates with very young and undeveloped soils. Most of the anthropogenically degraded soils and all mountainous and naturally poor soils (Greece) can be classified as "very poor" with final SQR values below 20, whereas former arable sites usually exhibit considerably better soil-quality conditions with SQR scores only slightly below 40. Sites with similar $S Q R$ values are frequently found in German low mountain ranges and in the eastern German lowlands (BGR, 2013) at sites which are in use for agriculture. Thus, abandoned arable lands offer at least some minor potential for traditional agricultural land use options. 
Table 5. Average biomass yields at case study sites: ranges for different degrees of soil marginality (data provided by regional project partners).

\begin{tabular}{|c|c|c|c|}
\hline Region & $\begin{array}{l}\text { Local site name } \\
\text { (village/town) }\end{array}$ & Cultivated bioenergy crop & $\begin{array}{r}\text { Biomass yields } \\
\left(\mathrm{t} \mathrm{DM} \mathrm{ha}^{-1} \mathrm{a}^{-1}\right)\end{array}$ \\
\hline \multicolumn{4}{|c|}{ Ukraine } \\
\hline Poltava & Semeniwka & Panicum virgatum/Miscanthus $\times$ giganteus & $10.0 \ldots 18.1$ \\
\hline Vinnitsa & Yaltushky & Panicum virgatum/Miscanthus $\times$ giganteus & $12.0 \ldots 15.3$ \\
\hline Volyn & Zubylne/Kysylyn & Salix sp./Populus sp. & $5.5 \ldots 6.0$ \\
\hline Lviv & Welyki Mosty & Salix sp./Populus sp. & $3.5 \ldots 6.0$ \\
\hline \multicolumn{4}{|c|}{ Greece } \\
\hline \multirow[t]{3}{*}{ East Macedonia \& Thrace } & Drosia & Pinus nigra & $7.2 \ldots 8.3$ \\
\hline & Pelagia & Pinus brutia & 2.8 \\
\hline & Sarakini & Robinia pseudoacacia & 2.3 \\
\hline \multicolumn{4}{|c|}{ Germany } \\
\hline Lower Lusatia (State & Welzow & Robinia pseudoacacia & $3.0 \ldots 5.0$ \\
\hline of Brandenburg) & Cottbus & Robinia pseudoacacia/Populus sp. & 3.0 \\
\hline
\end{tabular}

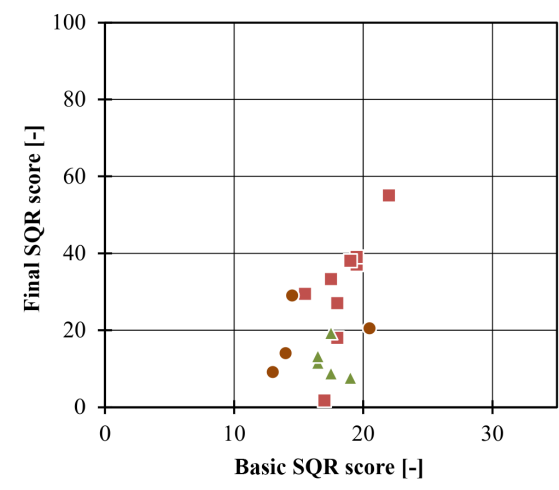

- Abandoned arable land

A Mountainous land

- Anthropogenically degraded land

Figure 4. Overview of SQR basic and final scores for investigated marginal case study sites.

The SQR system was primarily invented for traditional agricultural sites and its scores are well correlated with agricultural crop yields (Hennings et al., 2016; Mueller et al., 2010, 2016). By definition marginal lands are not suitable for agriculture and are described as "surplus land" (Dauber et al., 2012). The basic aim of the SQR system is to evaluate soil productivity functions related to traditional agricultural land use (Mueller et al., 2007, 2010) so that the assessment of land marginality is not within the original focus of the method. For validating the reliability of the SQR method for bioenergy crops, correlations between (estimated) biomass yields and SQR final scores were tested. Table 5 gives an overview of bioenergy crops cultivated at the studied sites and ranges of the estimated biomass yields as reported by regional project partners for sites with similar degrees of marginality. The estimated local biomass yields of marginal sites used here are in the majority of cases clearly below

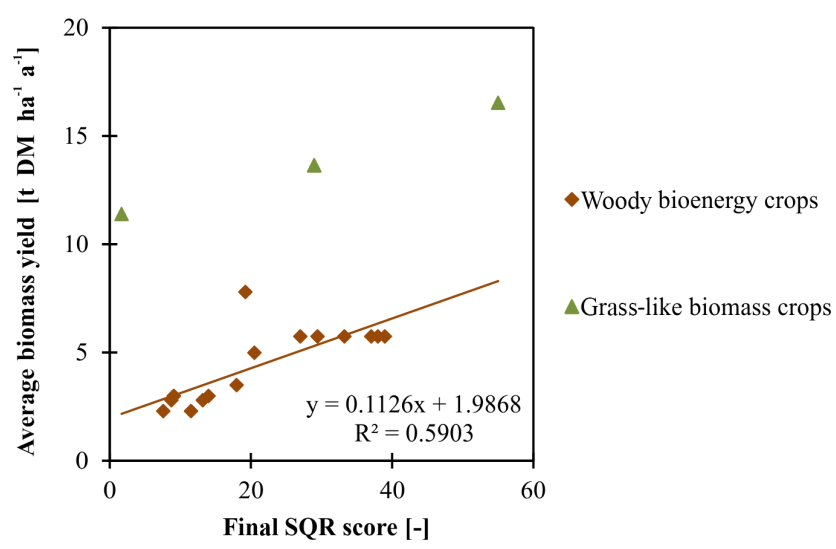

Figure 5. Correlation between final SQR scores and estimated average biomass yields for woody bioenergy crops with linear regression line $\left(n=16, r=0.84^{* *}, p<0.01\right)$ and grass-like bioenergy crops $(n=4$, no correlation coefficient available.).

biomass yields as reported in literature. For example, CliftonBrown et al. (2001) found mean biomass yields for miscanthus in Europe of $18 \mathrm{t} \mathrm{DM} \mathrm{ha}^{-1} \mathrm{a}^{-1}$. For woody biomass from short rotation plantations in Europe, Djomo et al. (2015) published an average of $9.3 \mathrm{tDM} \mathrm{ha}^{-1} \mathrm{a}^{-1}$.

Figure 5 illustrates the relationship between SQR final scores and estimated biomass yields for the investigated test sites, and separately for grass-like and woody bioenergy crops. A trend of growing biomass yield with decreasing marginality (increasing SQR scores) is visible from the figure for grass-like bioenergy crops, which are cultivated at two of the Ukrainian test sites. The correlation, however, of woody bioenergy crops with final SQR scores as an indicator of site marginality turns out to be strong and statistically sig- 
nificant (Fig. 5). It can be preliminarily concluded, therefore, that SQR scores are suitable to represent the productivity, or conversely the marginality, of soils with regard to yield potentials of bioenergy crops. Further, it becomes visible from this analysis that poor and also very poor sites with regard to soil conditions provide at least a certain potential for biomass production. The authors are aware of the necessity of an increasing number of investigations to be able to derive transferable results and trends. The presented results are valid for perennial bioenergy crops, mainly for fast-growing tree species. Effects of soil quality on the performance of annual bioenergy crops have not been considered. In addition, further research might be needed to analyse relations between soil quality and characteristics of biomass with regard to its later use in power plants or bio-refineries.

\subsubsection{Ecological constraints of marginal lands as expressed by SQR hazard indicators}

SQR hazard indicators are site properties which are able to critically affect the total soil quality (Mueller et al., 2007). Analysing the importance of the different hazard indicators of marginal lands allows for identifying generic factors of marginality which superimpose other properties. Previous studies (BGR, 2013; Hennings et al., 2016) showed that large areas of agricultural land are generally not limited by any hazard indicator. For German agricultural lands, Hennings et al. (2016) calculated an amount of $61.5 \%$ without any ecological constraint according to the SQR assessment. The remaining $38.5 \%$ of arable lands in Germany show different ecological limitations and about $6 \%$ of the arable lands can be seen as clearly marginal with final SQR scores below 40 . Against this background, the relevance of individual hazard indicators for marginality of the selected case study sites presented here was further elaborated. By clustering the investigated case study sites considering their hazard indicators, four groups of marginal lands could be revealed (Fig. 6). The average influence values of the respective hazard indicators for each cluster are shown in Table 6 .

Cluster 1 mainly represents the post-mining sites studied in Lower Lusatia (Germany). Soils at these sites are predominantly affected by higher acidification potentials and a low nutritional status. The same is true for one of the western Ukrainian sites, which is therefore part of this cluster.

The large cluster 2 integrates the further Ukrainian abandoned former arable lands, also including the former municipal waste dump sites in the Vinnitsa region. The main hazards related to these soils are the danger of seasonal over-wetting due to flooding or extreme waterlogging. Several of these sites are situated in depressions of the flat landscapes and/or exhibit a dense layer in the subsurface. The second relevant hazard found here was the insufficient nutritional status of the soils. Both factors can be seen as the reason for abandoning these former agricultural sites during the last two decades.

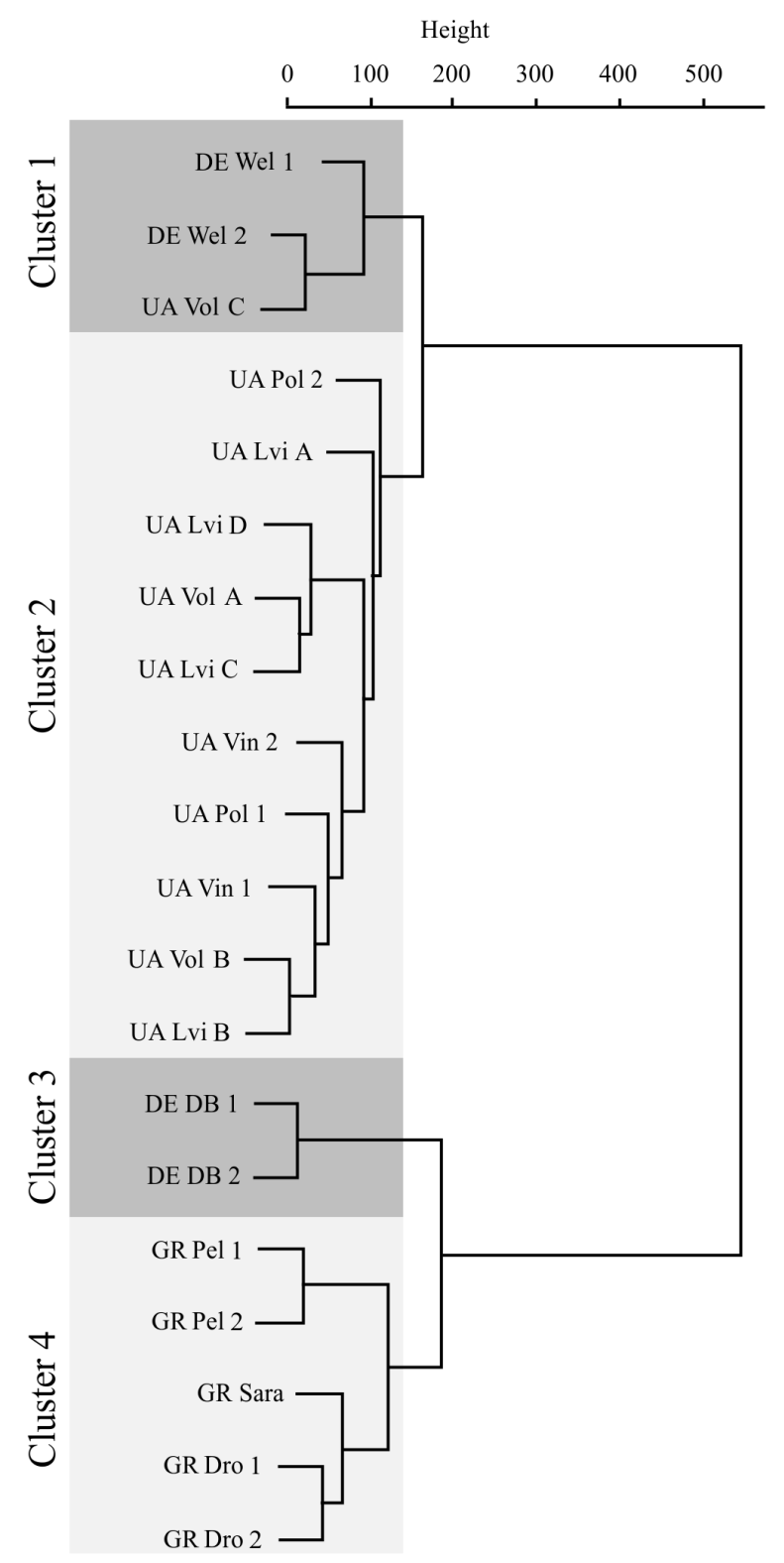

Figure 6. Investigated marginal case study sites grouped into four clusters based on influence values of their SQR hazard indicators.

Extreme soil conditions were found at the German postindustrial site (former railway area), which was grouped into cluster 3. Main hazards here are the very high amount of coarse particles above and in the soil substrate. These particles consist of remains of railroad ballast as well as rubble from former buildings at this site. This composition can be seen as typical for brownfields. The investigated site showed no signs of contamination.

Cluster 4 contains the Greek sites, which were already characterized as marginal sites with naturally poor soil conditions. With its Mediterranean climate regime, Greece is generally prone to droughts during the summer season. Further- 
Table 6. Mean influence values (0: no influence; 1.0 : maximum influence) of hazard indicators (H 1-11) for clusters of marginal case study sites (numbers in bold are the dominating values for the respective cluster).

\begin{tabular}{|c|c|c|c|c|c|c|c|c|c|c|c|}
\hline & $\begin{array}{r}\mathrm{H} 1 \\
\text { Contamination }\end{array}$ & $\begin{array}{r}\text { H } 2 \\
\text { Salinization }\end{array}$ & $\begin{array}{r}\text { H } 3 \\
\text { Sodification }\end{array}$ & $\begin{array}{r}\mathrm{H} 4 \\
\text { Acidification }\end{array}$ & $\begin{array}{r}\text { H } 5 \\
\text { Soil nutrient } \\
\text { status }\end{array}$ & $\begin{array}{r}\text { H } 6 \\
\text { Depth above } \\
\text { rock }\end{array}$ & $\begin{array}{r}\text { H } 7 \\
\text { Drought } \\
\text { risk }\end{array}$ & $\begin{array}{r}\mathrm{H} 8 \\
\text { Flooding/ } \\
\text { waterlogging }\end{array}$ & $\begin{array}{r}\text { H } 9 \\
\text { Slope }\end{array}$ & $\begin{array}{r}\text { H } 10 \\
\text { Stones } \\
\text { at the } \\
\text { surface }\end{array}$ & $\begin{array}{r}\text { H } 11 \\
\text { Coarse } \\
\text { soil } \\
\text { fragments }\end{array}$ \\
\hline Cluster 1 & 0.00 & 0.22 & 0.00 & 0.49 & 0.23 & 0.00 & 0.00 & 0.01 & 0.00 & 0.00 & 0.00 \\
\hline Cluster 2 & 0.04 & 0.04 & 0.02 & 0.00 & 0.13 & 0.07 & 0.01 & 0.28 & 0.00 & 0.03 & 0.03 \\
\hline Cluster 3 & 0.03 & 0.05 & 0.00 & 0.00 & 0.05 & 0.00 & 0.00 & 0.00 & 0.00 & 0.50 & 0.77 \\
\hline Cluster 4 & 0.45 & 0.00 & 0.00 & 0.00 & 0.20 & 0.34 & 0.63 & 0.00 & 0.07 & 0.39 & 0.71 \\
\hline
\end{tabular}

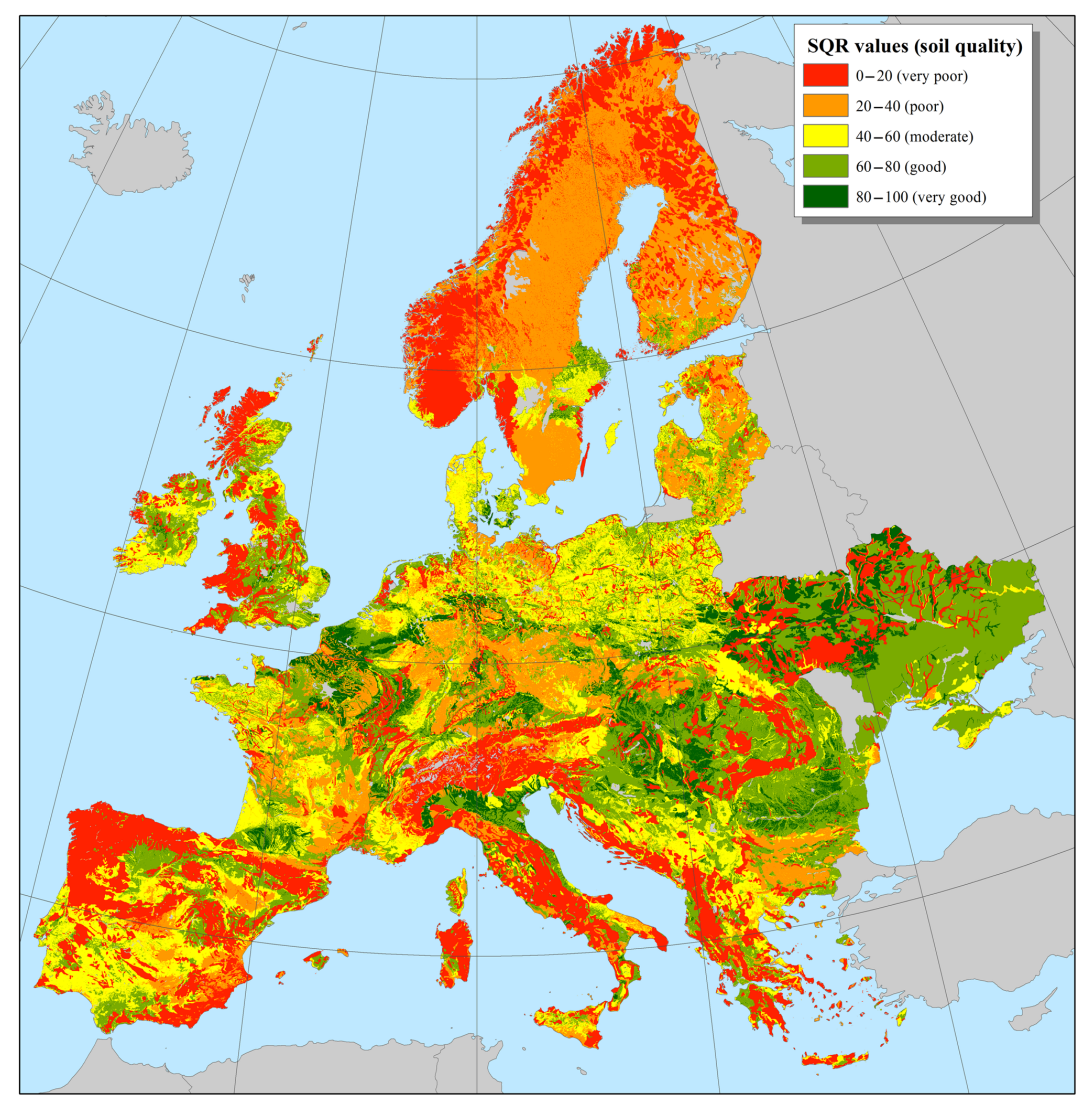

Figure 7. SQR calculation results for Europe taking into account all basic and 11 hazard indicators.

more, soil substrates are in part extremely stony both at the surface and within the profile. It is assumed that the geology of the Rhodope Mountains in northern Greece with frequent ore deposits provides slightly elevated background contents of heavy metals $(\mathrm{Cr}, \mathrm{Ni})$ and arsenic (As) so that the contamination hazard indicator gained higher influence. In addition, as a result of previous erosion, the remaining soil profiles are mainly shallow with low depths above hard rock. This is consistent with conclusions by Hennings et al. (2016) who found low soil depth as an important SQR hazard indicator in mountain regions of Germany.

\subsection{Quantification of marginal-land potentials in Europe}

Marginal land in Europe was quantified using the developed GIS tool. The first outcome was the calculation of the SQR index incorporating all 8 basic indicators and 11 hazard indicators (H 2: salinization, H 3: sodification, $\mathrm{H} 4$ : acidification, H 6: soil depth above hard rock, H 7: drought, H 8: flooding or extreme waterlogging, $\mathrm{H}$ 9: steep slope, $\mathrm{H}$ 10: rock at the surface, $\mathrm{H} \mathrm{11:} \mathrm{high} \mathrm{percentage} \mathrm{of} \mathrm{coarse} \mathrm{soil} \mathrm{texture}$ fragments, $\mathrm{H}$ 12: unsuitable soil thermal regime and $\mathrm{H} \mathrm{13}$ : disturbance by humans). The produced map with the SQR value classes is presented in Fig. 7. Approximately $257 \mathrm{Mha}$ 


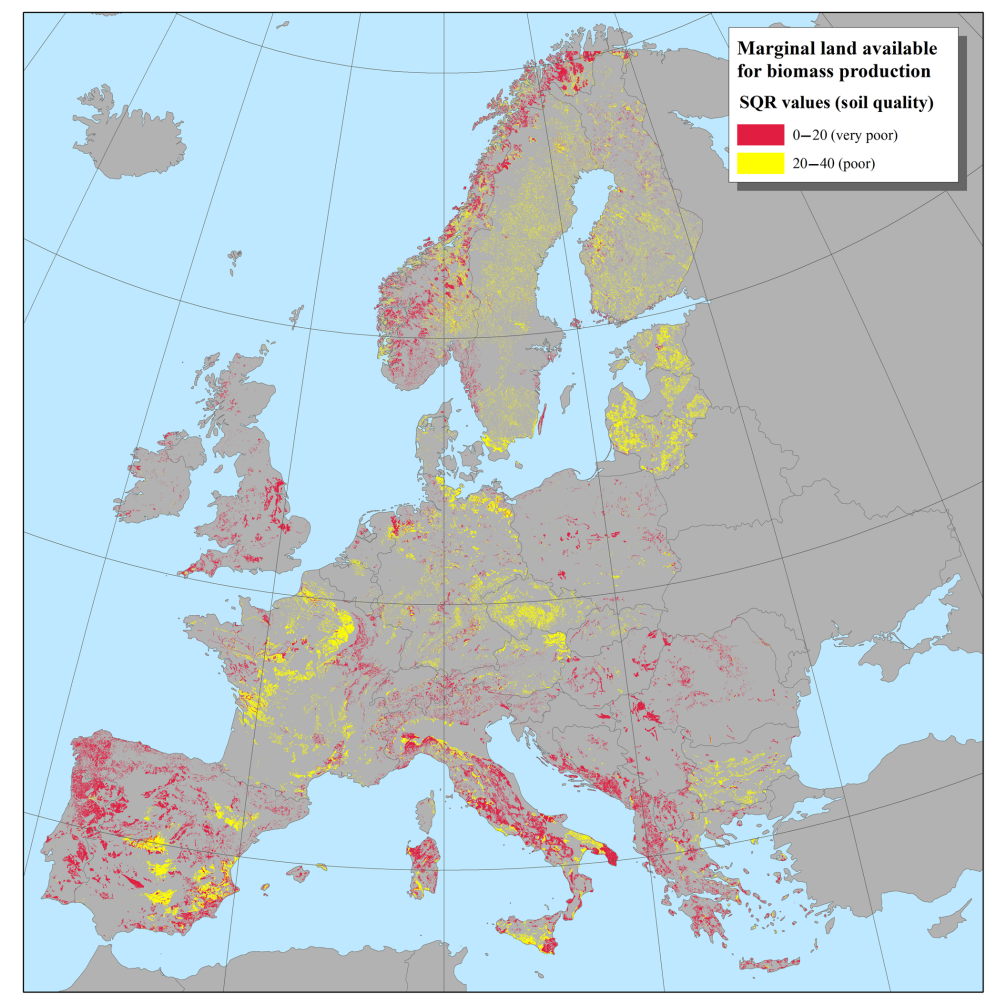

Figure 8. Marginal land available for biomass production for bioenergy purposes in Europe.

of land in Europe ${ }^{1}$ belongs to the poor and very poor classes of the SQR index and is identified as marginal. This area corresponds to $46 \%$ of the overall area investigated.

The marginal land available for biomass production for bioenergy purposes, calculated after implementation of the proper elimination criteria (protected areas, specific land uses, and slope steepness), is depicted in Fig. 8. The area of the sites with marginal soil conditions available for biomass production is approximately $58.2 \mathrm{Mha}$. This figure represents $10.5 \%$ of the overall area of Europe and $22.6 \%$ of the overall marginal land in the region. With this area size, previous estimates of current land potentials for bioenergy production in Europe are clearly exceeded. Kluts et al. (2017) gave an overview on such studies. According to them, the minimum area of land currently available in Europe for bioenergy production was estimated as being clearly below 10 Mha. The maximum number was $30 \mathrm{Mha}$. The approach presented here only estimates the potential availability of land with poor or very poor soil quality which is considered to be unsuitable

\footnotetext{
${ }^{1}$ Albania, Andorra, Austria, Belgium, Bosnia and Herzegovina, Bulgaria, Croatia, Czech Republic, Denmark, Estonia, Finland, France, FYROM, Germany, Greece, Hungary, Ireland, Italy, Latvia, Liechtenstein, Lithuania, Luxembourg, Malta, Monaco, Montenegro, the Netherlands, Norway, Poland, Portugal, Romania, San Marino, Serbia, Slovakia, Slovenia, Spain, Sweden, Switzerland, United Kingdom, and Ukraine
}

for conventional agriculture. It must be assumed that an unknown proportion of this area is most probably unsuitable for biomass production due to extreme site conditions. Thus, minimum soil quality for sustainable use of marginal lands has to be defined in future steps. For this purpose it will be necessary to further investigate the relationship between soil quality and biomass yield more precisely.

The countries with the highest percentages of marginal lands in relation to their overall area $(>20 \%)$ are in descending order: San Marino, Albania, Portugal, Italy, Lithuania, and Norway (Fig. 9). The corresponding percentages for the countries with SEEMLA case study sites are $14.6 \%$ (1.9 Mha) for Greece and 9.4\% (3.3 Mha) for Germany, while for Ukraine these figures could not be calculated due to the lack of geospatial data regarding the availability of marginal land for biomass production in the country.

According to the SQR methodology, land marginality can be attributed either to unfavourable soil substrates or to the influence of specific hazard indicators. The GIS analysis showed that poor soil conditions, not influenced by any hazard indicator of the SQR system, account for $34 \%$ (19.7 Mha) of marginal lands available for biomass production in Europe, whereas areas with marginality owing to one or more hazard indicators account for the remaining $66 \%$ (38.6 Mha; Fig. 10). Generic soil parameters are jointly considered in the calculation of the SQR value as the weighted sum of the basic indicators, with values below 13 to indicate 


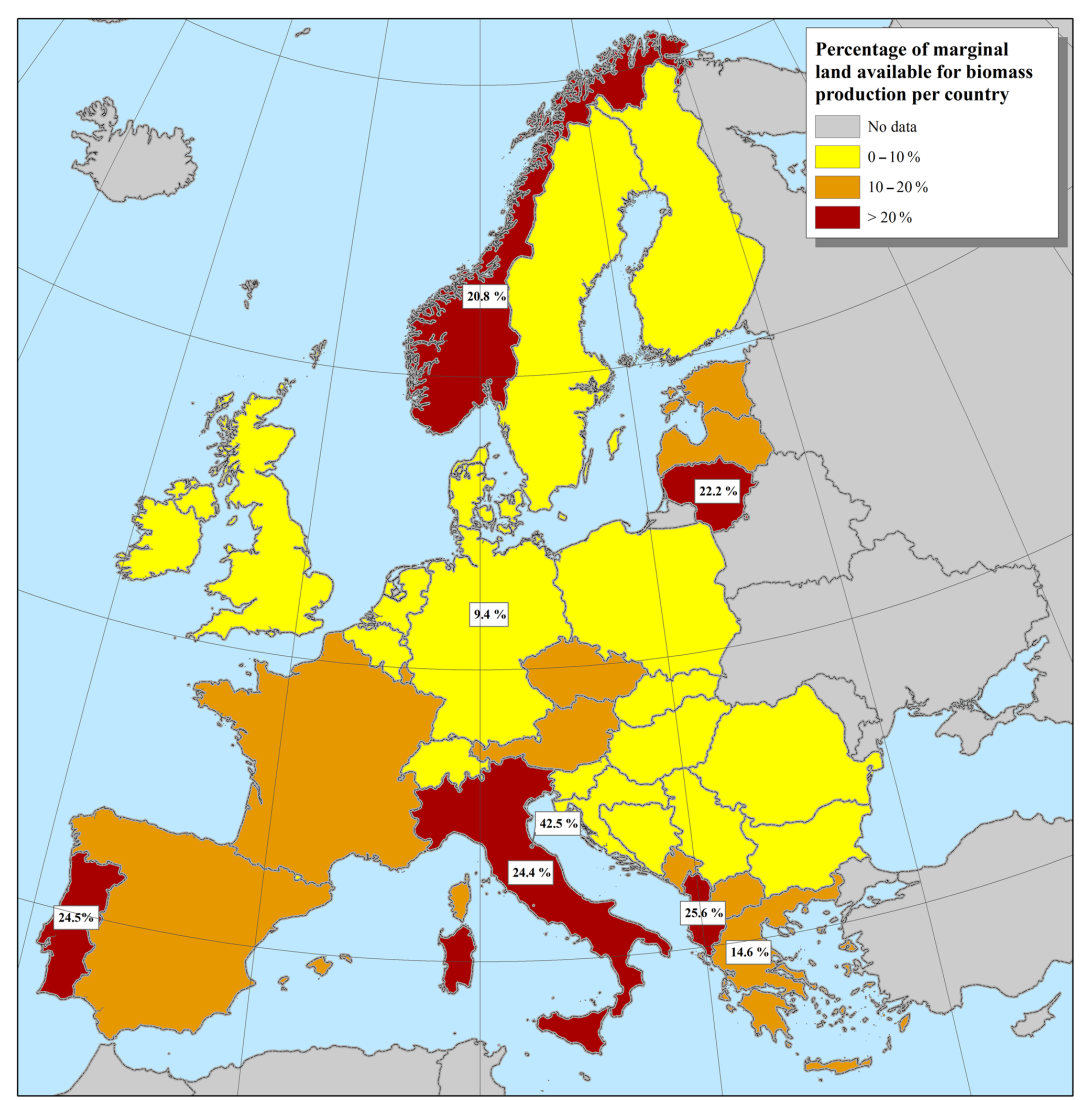

Figure 9. Percentage of marginal land available for biomass exploitation per country.

land marginality (1.03 Mha). In the case of missing values for any of the basic indicators the SQR score is not calculated, ensuring that all basic indicators are taken into account.

Hazard indicators, on the other hand, have an additive effect to the SQR calculation, in the sense that a single hazard indicator is sufficient to classify an area as marginal. Thus, applying as many of these potential marginality factors as possible provides a more precise estimation. Even though the overall area affected by a specific hazard may be limited, its importance can be significant at local level. The importance of each hazard indicator should therefore be assessed locally, regardless of the overall area it affects, based on its scale of influence (values ranging between 1.0 - hazard of relevance for a site - and 0 - no hazard influence detectable). Hazard indicators with scale of influence over 0.5 account for land marginality in most European countries (Fig. 10).

Regarding marginal lands in Europe, three SQR hazard indicators turned out to be most widespread (Table 7 and Fig. 11): $47.3 \%$ of the marginal lands are characterized by shallow soils (H 6: soil depth above hard rock), $13.8 \%$ are affected by unsuitable soil thermal regimes (H 12), and $3.2 \%$ are endangered by drought risks (H 7). Shallow soils are frequent in the Mediterranean region as a result of extensive erosion processes in the past since antiquity as well as in
Scandinavia with young post-glacial soils. Drought risks are mainly restricted to the Iberian Peninsula, whereas unsuitable soil thermal regimes are typical for the northern parts of Scandinavia and the Alps, both with harsh climatic conditions.

The overall area of influence of the hazard indicators is slightly higher due to the fact that in some sites there are more than one determinant marginality factor, accounting for the difference of $0.25 \mathrm{Mha}$ arising between the two numbers reported (38.6 Mha overall area versus 38.85 Mha in Table 7).

While the impact of H 6 (soil depth above hard rock) extends to all of Europe, the influence of the other two hazard indicators is localized. Drought risk (H 7) is a significant marginality factor for the Mediterranean (mostly Spain and Italy), whereas unsuitable soil thermal regime accounts for the marginality of most areas in Nordic countries (mostly Finland and Sweden) (Fig. 11).

The soil substrates, in combination with the marginality factors and ecological demands of the plants, determine the bioenergy crops that are suitable for each marginal land. The criteria that were taken into account for the selection of the bioenergy crops include the following: drought risk, $\mathrm{pH}$, wetness and ponding, altitudinal range, and biogeographical re- 


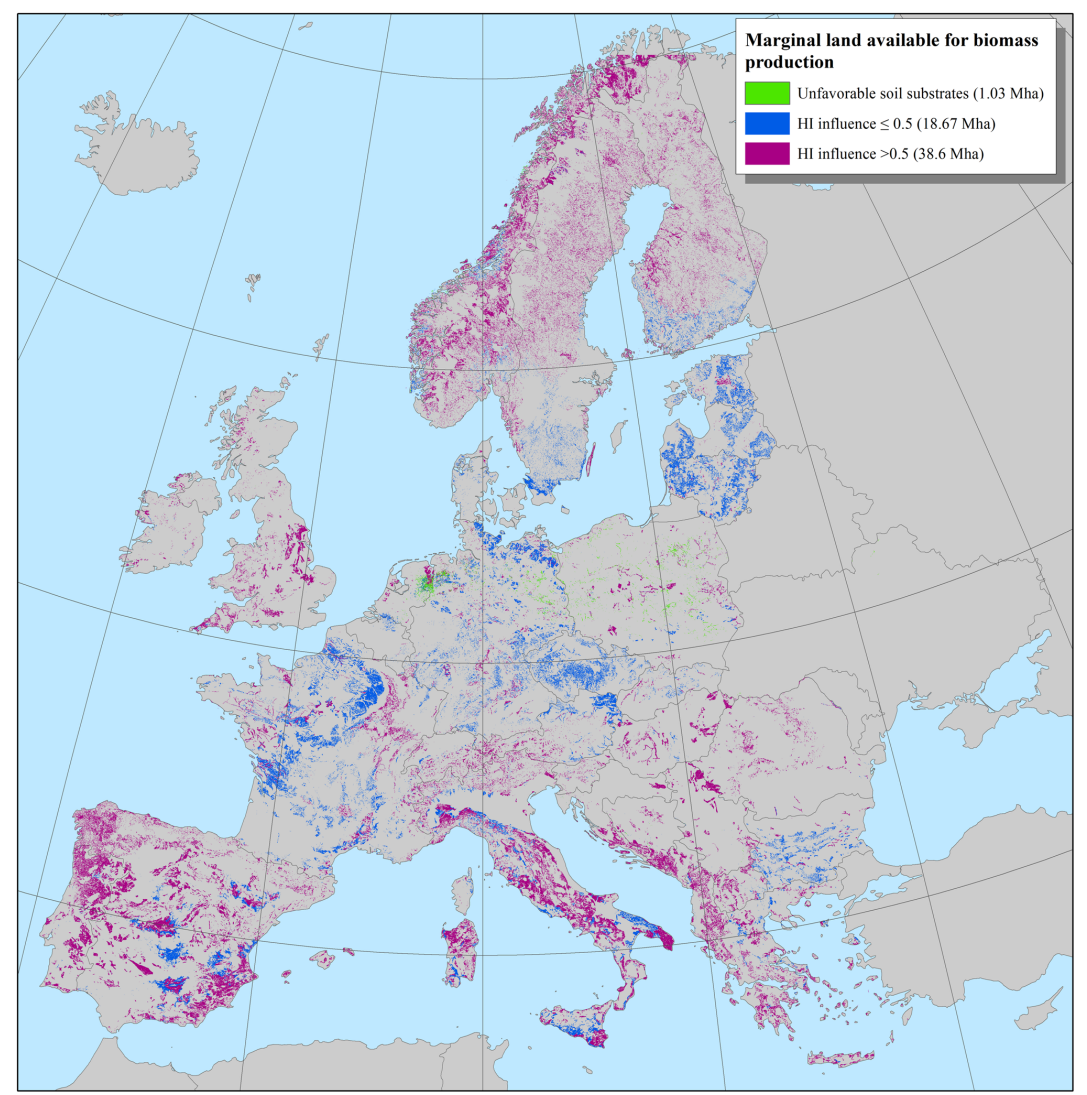

Figure 10. SQR hazard indicators area of influence as marginality factors in Europe.

Table 7. Extent of different soil-related hazard indicators for European marginal lands. Hazard indicators with the highest spatial influence on marginality (area $>1.0 \mathrm{Mha}$ ) are given in bold letters.

\begin{tabular}{llrr}
\hline \multicolumn{1}{c}{ Hazard indicator } & $\begin{array}{r}\text { Area } \\
(\text { Mha })\end{array}$ & $\begin{array}{r}\text { Marginal land influenced } \\
\text { at the European scale (\%) }\end{array}$ \\
\hline H 2 & Salinization & 0.05 & $0.09 \%$ \\
H 3 & Sodification & 0.04 & $0.07 \%$ \\
H 4 & Acidification & 0.19 & $0.32 \%$ \\
H 6 & Soil depth above hard rock & $\mathbf{2 7 . 8 6}$ & $\mathbf{4 7 . 3 4 \%}$ \\
H 7 & Drought risk & $\mathbf{1 . 8 7}$ & $\mathbf{3 . 1 9 \%}$ \\
H 8 & Flooding or extreme waterlogging & 0.25 & $0.42 \%$ \\
H 9 & Steep slope & 0.08 & $0.13 \%$ \\
H 10 & Rock at the surface & 0.26 & $0.44 \%$ \\
H 11 & High percentage of coarse soil texture fragments & 0.07 & $0.13 \%$ \\
H 12 & Unsuitable soil thermal regime & $\mathbf{8 . 1 2}$ & $\mathbf{1 3 . 8 0 \%}$ \\
H 13 & Disturbance by humans & 0.04 & $0.07 \%$ \\
& Sum & 38.85 & $66.00 \%$ \\
\hline
\end{tabular}

gion. The threshold values for the selected bioenergy crops are cross-referenced with the site parameters in order to locate the areas of interest. An overview of the marginal land that is suitable for selected bioenergy crops (basket willow, black locust, black pine, miscanthus, poplar, and switchgrass) is presented in Fig. 12. The area has been classified per species or species group in order to map those with the wider range in Europe, taking into account that in most cases more than one plant species can be grown in a specific site. Particularly, basket willows and poplars have large overlapping potential growing areas in western and central Europe 


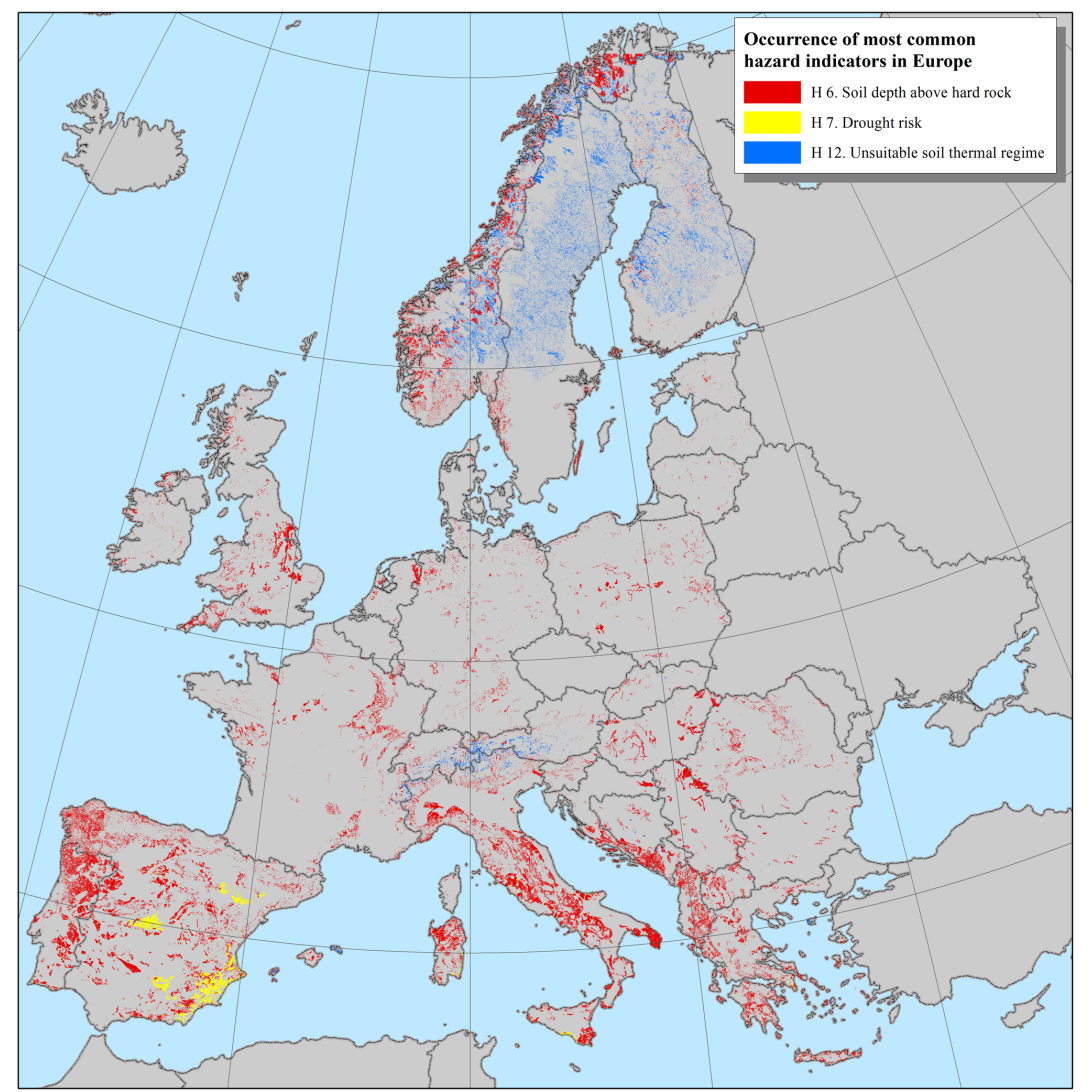

Figure 11. Occurrence of the most common hazard indicators $(\mathrm{H} 6, \mathrm{H} 7$, and $\mathrm{H} 12)$ in Europe.

and can be found, therefore, in different groups of bioenergy crops of Fig. 12.

The area of marginal land that can be exploited for biomass production with the use of the selected bioenergy crops is approximately $44.62 \mathrm{Mha}$, which is less than $80 \%$ of the overall marginal land that was originally identified as suitable (58.2 Mha). The ecological demands of the plant species act as another constraining factor for marginal-land exploitation, further reducing the available area. Based on results of the GIS analysis, poplar can be grown in most of the sites, contrary to black pine and miscanthus (Table 8). Land marginality is a fundamental limiting factor for plant growth. Therefore, the selection of the most adapted species to these extreme conditions is of major importance to sustainable biomass production.

The suitability of a marginal land for cultivation of bioenergy crops does not assure sustainable bioenergy production yet. Feedstock quantities and continuous supply, cultivation and harvesting techniques, feedstock transportation and processing to final bioenergy products, and other aspects of the whole value chain should be considered. Moreover, the impact of bioenergy production on the environmental, economic, and social conditions of a region should be studied. Such concerns have been included in a set of exploitation sce- narios of marginal lands that are currently being examined. Each scenario includes life-cycle assessment (LCA), life cycle environmental impact assessment (LC-EIA), and an analysis of social and economic aspects, which will collectively determine the sustainability of biomass exploitation.

The SEEMLA algorithm will be further developed in the near future to provide a decision support tool for the exploitation of marginal lands for bioenergy production. This process involves the incorporation of the sustainability assessment results of the exploitation scenarios in combination with the results from the case study sites. The final step for the algorithm development will be to rate marginal lands, assigning priorities for cultivation to them according to the most efficient exploitation scenario.

\section{Outlook on policies and legal frameworks for utilization of marginal land}

In the previous sections the potential availability of marginal land for biomass production has been illustrated. However, current EU and national policies neither include nor explicitly describe aspects of marginal-land use. Instruments for mobilising and fostering the use of marginal lands in terms 


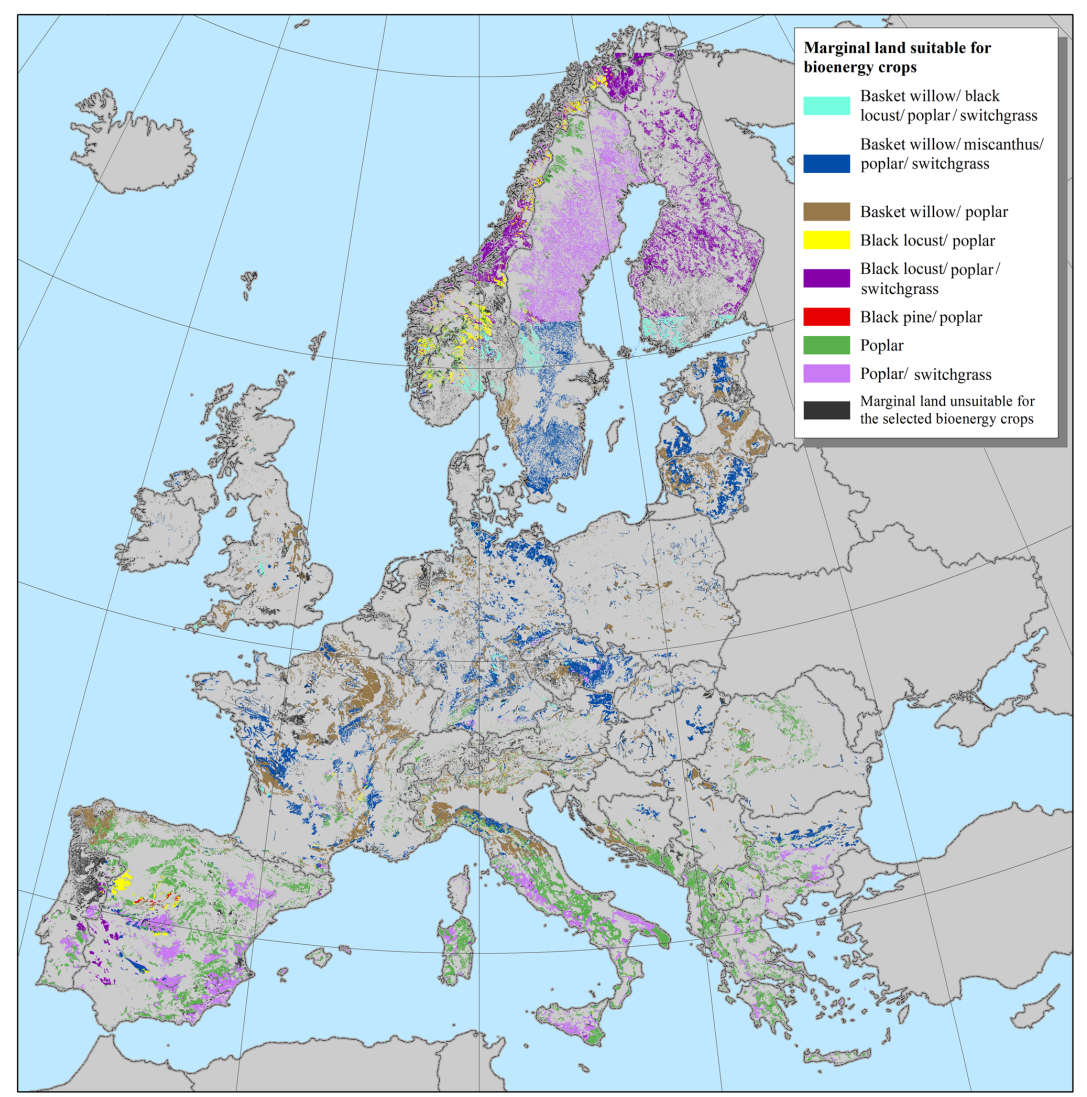

Figure 12. Marginal land suitability for bioenergy crops.

Table 8. Marginal lands available for biomass production per bioenergy crops.

\begin{tabular}{lrr}
\hline Bioenergy crop & $\begin{array}{r}\text { Area } \\
\text { (Mha) }\end{array}$ & $\begin{array}{r}\text { Percentage of marginal land available } \\
\text { for biomass production (\%) }\end{array}$ \\
\hline Salix viminalis & 18.57 & $41.88 \%$ \\
Robinia pseudoacacia & 6.52 & $14.70 \%$ \\
Pinus nigra & 1.28 & $2.87 \%$ \\
Miscanthus $\times$ giganteus & 5.36 & $12.01 \%$ \\
Populus sp. & 43.15 & $97.32 \%$ \\
Panicum virgatum & 21.05 & $47.47 \%$ \\
\hline
\end{tabular}

of abandoned, degraded, or economically inefficient land are missing.

Nevertheless, the overall framework for a sustainable biomass production for bioenergy is already established in the EU Renewable Energy Directives (RED; EC, 2009) and the member state National Renewable Energy Action Plans (NREAPs; EC, 2010), as well as in national legislation regarding environmental protection (including soil, water, air/atmosphere), biodiversity, agriculture, and forestry. However, an increasing demand for biomass needs to be related to an individual biomass potential in each country. So far, the estimated potentials vary a lot between European member states, and individual strategies are required to bridge the gaps of future energy demand (Scarlat et al., 2015). Therefore, the exploitation of biomass production for bioenergy in marginal land offers a great potential in order to be able to meet the 2020 targets and beyond.

With regard to biomass production in marginal lands, an early stage of market deployment has to be considered. In Table 9 , corresponding policy mechanisms related to the use of marginal land for bioenergy purposes are given. At this stage of initial market development, a strategy and action plan are crucial. Main financial support tools are R\&D grants, investment subsidies, loans, or credit lines, followed by tax exemptions in the transgression state from the initial to the early stage. However, major aims are (i) to create an attractive in- 
centive programme for stakeholders, i.e. farmers, foresters, to use marginal lands for sustainable biomass production for bioenergy; (ii) to share experiences in each country internally and transnationally with other EU member states; and (iii) to apply the EU Common Agricultural Policy (CAP; EC, 2013b) and find a way to adapt "marginality" to the CAP, e.g. "greening", and other relevant legislation, e.g. European water protection, nature conservation, soil protection, nitrates directive and related regulations, frameworks, and financial supporting programmes.

\subsection{Regulations suitable for biomass from marginal lands}

Based on recommendations of the BiomassPolicies project (see https://ec.europa.eu/energy/intelligent/projects/en/ projects/biomasspolicies/, last access: 3 December 2018) and adapted to SEEMLA, it has to be ensured that CAP measures from pillar 1 "direct payments" and pillar 2 "rural development" are integrated into local planning and that there are provisions for biomass from marginal lands. In detail, CAP pillar 2 targeted national and/or regional rural development programmes should be introduced (where they are not existing) focusing on a shift to a low-carbon economy, including targeted measures for municipalities. Action plans are to be developed including all measures dealing with the use, management, conservation, and protection of planted public areas where biomass production on marginal lands exists. Biomass certification activities need to be enhanced at the national level, whereas national preconditions are better taken into account by national policy.

\subsection{Financial support measures suitable for biomass from marginal lands}

With regard to CAP pillar 1 for direct payments, budget from "green direct payments" should include appropriate marginal-land management activities matched to regions, municipalities, local ecosystems, and practices. This will lead to optimized biomass mobilization. Subsidies for improving the types of species in marginal lands with (indigenous) fast-growing species should be offered as well as for small and medium-sized enterprises, cities, municipalities, etc. in order to purchase equipment for improved harvesting and handling operations (chippers, pelletizers, etc.). The preparation of a marginal-land management plan need to be supported and be provided in the form of grant or tax exemptions for improving existing biomass trade centres to include such biomass forms in their selling products. Similar funding systems, e.g. the European Regional Development Fund (ERDF) may function as an example. However, as in this case, aspects of a sustainable use of marginal lands with a special focus on biomass production for bioenergy purposes need to be defined. In any case, it will be essential to bridge differences in agricultural and bioenergy policies in European countries, supporting underdeveloped regions, and avoiding an increase in land degradation by supporting a sustainable land management.

\subsection{Information provision mechanisms suitable for biomass from marginal lands}

Knowledge should be transferred and human resource capital at the local municipality level should be improved. Capacity building for improved practices should be provided with regard to quality, handling, and storage of biomass from marginal lands, as well as capacity building to existing wood trade centres on handling biomass from marginal land. Learning from good practices is of great relevance for a successful development of a suitable SEEMLA approach and the foreseen introduction to the policy framework of the partner countries and, in mid-term perspectives, to EU legislation.

\section{Conclusions}

The study illustrates the large potentials but also some constraints of European marginal lands for contributing to a future energy supply based on renewable resources. In addition, the importance of a proper definition of marginal lands to be used as alternative areas for biomass production becomes clear. Sites to be announced as "marginal" vary extremely with regard to their soil properties and land use potentials. A number of potential soil-related hazards were identified to be the reason of marginality and also to limit the use of such sites for bioenergy production. In this regard, the SQR assessment method clearly demonstrated its ability to differentiate between fertile lands suitable for traditional agriculture and food production on the one hand and marginal sites which offer opportunities for future bioenergy production on the other hand.

Based on these results, potentially suitable areas for selected bioenergy crops were identified by means of low SQR scores using an innovative GIS approach. Generally, the SQR method turns out to be easy to apply during local field work as well as being useful for GIS assessment studies on site potentials at the continental scale. A clear advantage of the SQR system is its easy adaptability for GIS studies. The choice of input data, however, is still a demanding issue as soil-related datasets with higher spatial resolution are not available for all European countries. Further development of this GIS assessment approach will also need careful ground truthing of its results. Several open questions remain, particularly with regard to the accuracy of the input data and the resulting local soil classification.

Furthermore, open research questions remain with regard to the correlation between biomass yields and SQR scores. As the SQR method was primarily developed for agricultural crops, adaptations of the assessment system might be nec- 
Table 9. Policy mechanisms relevant to biomass from marginal land per value chain step, type of policy and market stage development (adapted from Panoutsou et al., 2016).

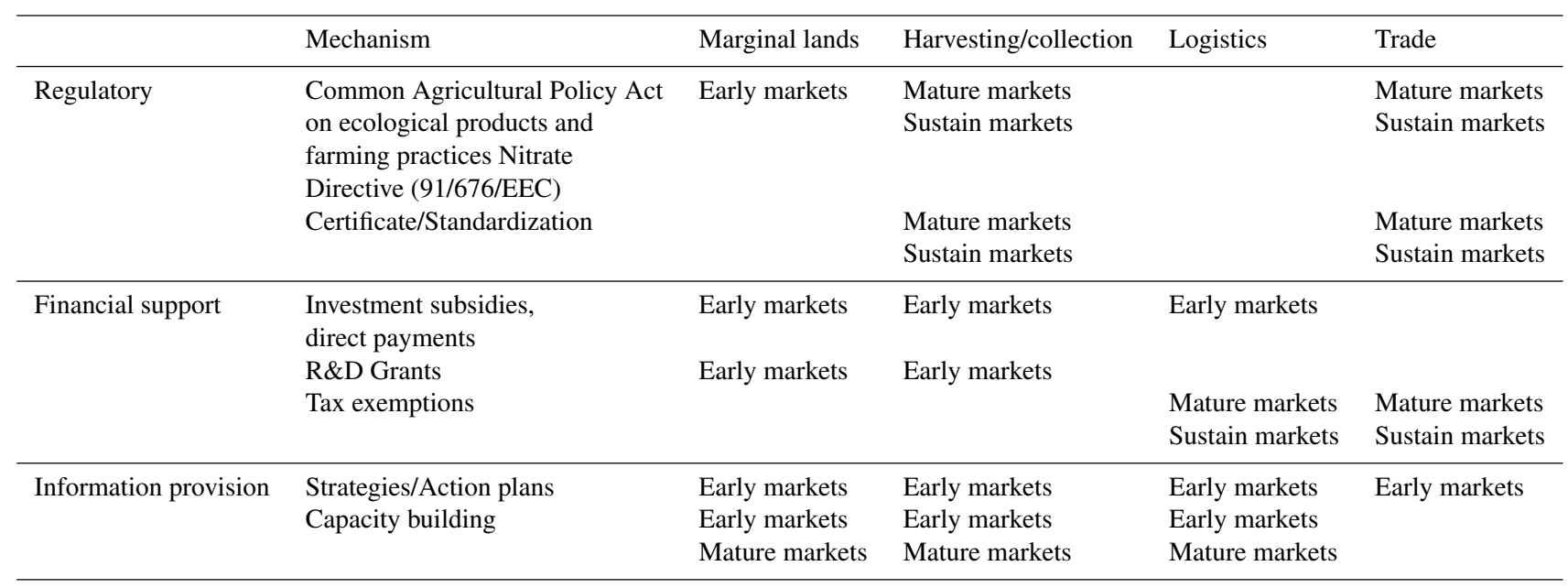

essary with regard to the ecological demands of bioenergy crops. Generally, yield data presented here suggest that sites with low SQR scores have a clearly reduced productivity, this is also true with regard to biomass yields of bioenergy crops. Therefore, the efficiency of biomass production must be considered as low at sites with very unfertile soils and might appear to be not very attractive for farmers to invest. However, examples from eastern European countries illustrate that the "re-cultivation" of set-aside lands with medium marginality might be an attractive option for local and regional value chains and socio-economic systems.

It is important to note that new conflicts might arise if soils, which are unproductive for agriculture under present socio-economic terms, are thought to be utilized for future bioenergy crop production. Often, marginal lands have been already set-aside for a long period of time or have been traditionally excluded from agriculture so that rare species and rare habitats are frequently found. Such sites are usually subject to nature conservation measures. A proper selection of suitable marginal lands and clear legal regulations are therefore crucial and explicitly needed for a sustainable production of energy from renewable resources. However, the proposed alternative land use systems for suitable marginal lands are supposed to be low input systems and can be considered to have, therefore, positive impacts on soil protection compared to intensive, conventional agricultural systems (Fernando et al., 2018).

The practical implementation of a sustainable biomass production for energetic use at marginal lands is, therefore, highly dependent on economic trade-offs as well as on supportive policy mechanisms and the framework of regulations. At present, a wide range of different national policies and regulations exists within European countries. This impedes an overall implementation of this approach and causes unnecessary reservations for local farmers, landowners, and au- thorities. Furthermore, additional financial support and incentives for farmers are still widely missing to overcome the relatively low efficiency of marginal soils compared with highly productive (food producing) soils. Integrating bioenergy production at suitable marginal lands into future European policies (e.g. CAP) and the creation of suitable incentive programmes might contribute to the objective to reach national and European renewable energy goals for 2050, and to mitigate the rising land use conflict between the production of food and feed, on the one hand, and biomass, on the other hand. It can be expected that the importance of marginal lands will increase during the next few decades as bioenergy is thought to play an important role for future energy supply in Europe in terms of being able to meet the targets for greenhouse gas emissions reduction until 2050.

Data availability. The core data set used for calculating SQR scores of the investigated field sites is given in Table A1 of Appendix A. Data for the GIS approach have been derived from publicly available sources as indicated in Table 4, mainly from ESDAC European Soil Database distribution v2.0 and FAO Harmonized World Soil Database (HWSD) v1.2. 
Appendix A

Table A1. Properties of investigated soil profiles at the investigated case study sites.

\begin{tabular}{|c|c|c|c|c|c|c|c|c|c|c|c|c|c|c|}
\hline & \multirow[t]{2}{*}{$\begin{array}{l}\text { Soil texture } \\
(\text { FAO classes })^{\mathrm{a}}\end{array}$} & \multirow[t]{2}{*}{$\begin{array}{l}\text { Bulk density }{ }^{\mathrm{b}} \\
\qquad\left(\mathrm{g} \mathrm{cm}^{-3}\right)\end{array}$} & \multirow[t]{2}{*}{$\begin{array}{r}\text { Rooting } \\
\text { depth } \\
(\mathrm{cm})\end{array}$} & \multirow[t]{2}{*}{$\begin{array}{r}\text { Profile } \\
\text { available } \\
\text { water } \\
(\mathrm{mm})\end{array}$} & \multirow[t]{2}{*}{$\begin{array}{r}\mathrm{EC}_{\mathrm{SE}}^{\mathrm{a}} \\
\left(\mathrm{mS} \mathrm{cm}^{-1}\right)\end{array}$} & \multirow[t]{2}{*}{$\mathrm{pH}_{\mathrm{H}_{2} \mathrm{O}}^{\mathrm{a}}$} & \multicolumn{2}{|c|}{$\begin{array}{c}\text { Plant } \\
\text { available } \\
\text { nutrients } \\
\left(\mathrm{mg} \mathrm{kg}^{-1}\right)\end{array}$} & \multicolumn{6}{|c|}{$\begin{array}{l}\text { Heavy-metal content } \\
\quad\left(\mathrm{mg} \mathrm{kg}^{\mathrm{c}}\right)\end{array}$} \\
\hline & & & & & & & $\mathrm{P}$ & K & As & $\mathrm{Cr}$ & $\mathrm{Cu}$ & $\mathrm{Ni}$ & $\mathrm{Pb}$ & $\mathrm{Zn}$ \\
\hline GR Pel 1 & SCL/SCL & 1.5 & 50 & 77.5 & $0.43 / 0.17$ & $5.3 / 6.3$ & 5 & 121 & 26 & 96 & 39 & 90 & - & 53 \\
\hline GR Pel 2 & SL/SCL & 1.5 & 50 & 80.0 & $0.56 / 0.32$ & $6.8 / 6.2$ & 1 & 77 & 25 & 136 & 30 & 50 & - & 43 \\
\hline GR Dro 1 & SCL/CL & 1.5 & 40 & 60.0 & $0.64 / 0.18$ & $6.4 / 5.7$ & 4 & 175 & 107 & 123 & - & 60 & - & 50 \\
\hline GR Dro 2 & SCL/SCL & 1.3 & 30 & 54.0 & $0.28 / 0.16$ & $6.0 / 5.7$ & 4 & 172 & 113 & 125 & - & 49 & - & 41 \\
\hline GR Sara & LS/LS & 1.7 & 60 & 102.0 & $1.40 / 0.43$ & $5.3 / 5.7$ & 4 & 44 & 23 & 320 & 36 & 215 & - & 49 \\
\hline DE DB 1 & MS/MS & 1.8 & 80 & 56.0 & $2.44 / 1.44$ & $8.0 / 7.2$ & 381 & 59 & 6 & - & - & 37 & 38 & 52 \\
\hline DE DB 2 & MS/MS & 1.8 & 80 & 56.0 & $1.91 / 0.56$ & $7.3 / 5.8$ & 53 & 24 & 7 & - & - & 35 & 56 & 42 \\
\hline DE Wel 1 & SL/SL & 1.5 & 90 & 157.5 & $1.22 / 0.97$ & $7.2 / 6.7$ & 3 & 13 & 7 & - & - & - & 26 & 10 \\
\hline DE Wel 2 & SL/LS & 1.8 & 70 & 105.0 & $0.71 / 1.16$ & $6.0 / 4.0$ & 5 & 36 & 4 & - & - & - & 24 & 13 \\
\hline UA Pol 1 & $\mathrm{HC} / \mathrm{SC}$ & 1.2 & 100 & 145.0 & $0.42 / 0.71$ & $7.8 / 8.4$ & 59 & 66 & 15 & 26 & - & - & 14 & 33 \\
\hline UA Pol 2 & $\mathrm{HC} / \mathrm{HC}$ & 1.6 & 140 & 182.0 & $0.37 / 0.11$ & $6.1 / 6.4$ & 93 & 114 & 8 & - & - & - & 25 & 23 \\
\hline UA Vin 1 & $\mathrm{HC} / \mathrm{SC}$ & 1.6 & 80 & 124.0 & $0.57 / 2.13$ & $7.3 / 7.8$ & 882 & 2574 & 19 & 46 & 20 & - & 27 & 70 \\
\hline UA Vin 2 & $\mathrm{C} / \mathrm{SC}$ & 1.7 & 80 & 124.0 & $0.49 / 3.29$ & $7.5 / 8.0$ & 891 & 416 & 20 & 64 & 36 & 40 & 113 & 132 \\
\hline UA Vol A & LS/LS & 1.7 & 80 & 124.0 & $0.93 / 0.40$ & $6.2 / 6.7$ & 15 & 18 & 6 & - & - & - & 16 & 16 \\
\hline UA Vol B & SCL/SCL & 1.7 & 80 & 88.0 & $0.78 / 0.54$ & $7.7 / 7.9$ & 19 & 44 & 5 & - & - & - & 23 & 9 \\
\hline UA Vol C & LS/LS & 1.7 & 70 & 91.0 & $0.54 / 0.33$ & $4.8 / 4.9$ & 35 & 13 & 5 & - & 21 & - & 16 & - \\
\hline UA Lvi A & $\mathrm{CL} / \mathrm{C}$ & 1.9 & 30 & 42.0 & $1.40 / 0.79$ & $7.5 / 7.9$ & 4 & 36 & 9 & - & - & - & 23 & 17 \\
\hline UA Lvi B & SL/SL & 1.8 & 90 & 166.5 & $1.43 / 1.53$ & $7.8 / 7.9$ & 23 & 83 & 9 & 17 & - & 35 & 15 & 41 \\
\hline UA Lvi C & LS/MS & 1.7 & 60 & 57.0 & $1.59 / 0.34$ & $6.5 / 5.7$ & 23 & 8 & - & - & - & - & 22 & 7 \\
\hline UA Lvi D & SCL/SCL & 1.8 & 90 & 130.5 & $0.89 / 0.77$ & $7.5 / 7.8$ & 6 & 22 & 5 & - & - & - & 21 & 27 \\
\hline
\end{tabular}

Data for: ${ }^{\mathrm{a}}$ topsoil/subsoil $/^{\mathrm{b}}$ subsoil/ ${ }^{\mathrm{c}}$ topsoil. 


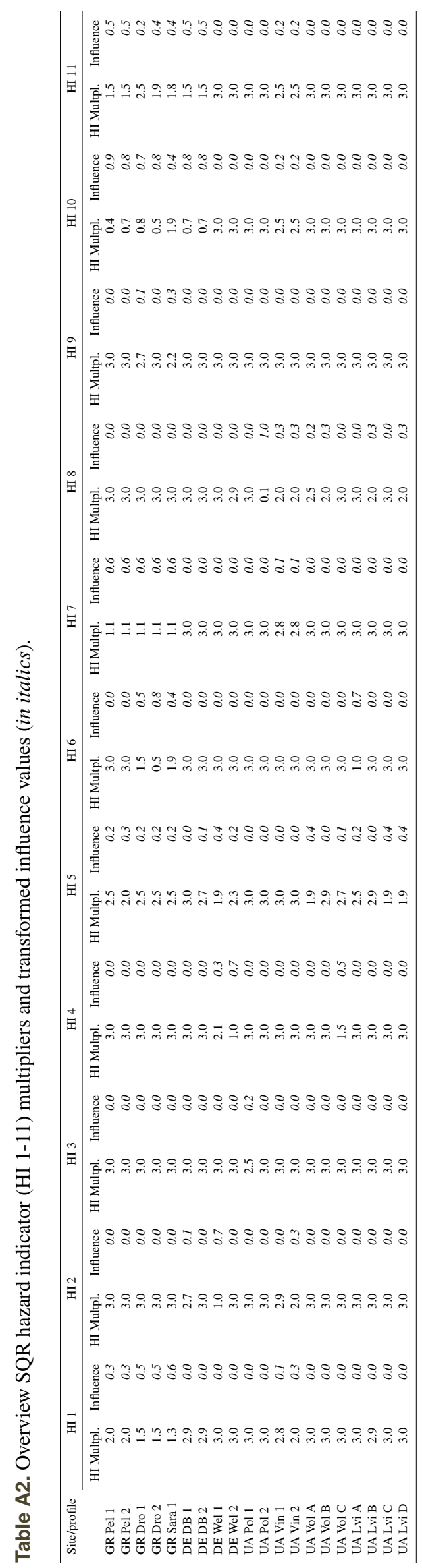


Author contributions. Field work, soil analysis, and quality assessment at case study sites were carried out by WG and FR, locally assisted by FK and DK. The GIS study was performed by SG, DV, and NG. The legal and policy framework was elaborated by WB. $\mathrm{DF}$ and $\mathrm{CV}$ contributed to data analysis and interpretation.

Competing interests. The authors declare that they have no conflict of interest.

Disclaimer. This paper reflects only the authors' view and the Innovation and Networks Executive Agency (INEA) as delegated by the European Commission is not responsible for any use that may be made of the information it contains.

Acknowledgements. This project "SEEMLA" received funding from the European Union's Horizon 2020 research and innovation programme under grant no. 691874. The authors would like to thank all SEEMLA project partners for their support during field work and sampling as well as for providing biomass yield data for the investigated case study sites.

Edited by: Giacomo Certini

Reviewed by: two anonymous referees

\section{References}

AG Boden: Bodenkundliche Kartieranleitung, Bundesanstalt für Geowissenschaften und Rohstoffe, Hannover, Germany, 2005.

Agronomic Interpretations Working Group: Land Suitability Rating System for Agricultural Crops: 1. Spring-seeded small grains, Tech. Bull. 1995-6E, Centre for Land and Biological Resources Research, Agriculture and Agri-Food Canada, Ottawa, 1995.

Batidzirai, B., Smeets, E. M. W., and Faaij, A. P. C.: Harmonising bioenergy resource potentials - Methodological lessons from review of the state of the art bioenergy potential assessments, Renew. Sust. Energ. Rev., 16, 6598-6630, https://doi.org/10.1016/j.rser.2012.09.002, 2012.

BGR, Bundesanstalt für Geowissenschaften und Rohstoffe: Ackerbauliches Ertragspotential eines Standorts, bemessen nach dem Müncheberger Soil Quality Rating (SQR), available at: https: //www.bgr.bund.de/DE/Themen/Boden/Netzwerke/AGBoden/ Downloads/Methode_6_3.pdf?_blob=publicationFile\&v=2 (last access: 3 December 2018), 2010.

BGR, Bundesanstalt für Geowissenschaften und Rohstoffe: Map of the agricultural yield potential of German soils, Hannover, Germany, 2013.

Blume, H.-P., Stahr, K., and Leinweber, P.: Bodenkundliches Praktikum, Spektrum Akademischer Verlag, Heidelberg, Germany, 2011.

Blume, H.-P., Brümmer, G. W., Fleige, H., Horn, R., Kandeler, E., Kögel-Knabner, I., Kretzschmar, R., Stahr, K., and Wilke, B.-M.: Scheffer/Schachtschabel, Soil Science, Springer, Berlin, Heidelberg, Germany, 2016.
Breuning-Madsen, H., Reenberg, A., and Holst, K.: Mapping potentially marginal land in Demark, Soil Use Manage., 6, 114-120, https://doi.org/10.1111/j.1475-2743.1990.tb00819.x, 1990.

Cai, X., Zhang, X., and Wang, D.: Land availability for biofuel production, Environ. Sci. Technol., 45, 334-339, https://doi.org/10.1021/es103338e, 2011.

Campbell, E. J., Lobell, D. B., Genova, R. C., and Field, C. B.: The Global Potential of Bioenergy on Abandoned Agricultural Lands, Environ. Sci. Technol., 42, 5791-5794, https://doi.org/10.1021/es800052w, 2008.

Clifton-Brown, J. C., Lewandowski, I., Andersson, B., Basch, G., Christian, D. G., Kjeldsen, J. B., Jørgensen, U., Mortensen, J. V., Riche, A. B., Schwarz, K.-U., Tayebi, K., and Teixeira, F.: Performance of 15 Miscanthus Genotypes at Five Sites in Europe, Agron. J., 93, 1013-1019, https://doi.org/10.2134/agronj2001.9351013x, 2001.

Dauber, J. and Miyake, S.: To integrate or to segregate food and energy crop cultivation at the landscape scale? Perspectives on biodiversity conservation in agriculture in Europe, Energy, Sustainability and Society, 6, 25, https://doi.org/10.1186/s13705-0160089-5, 2016.

Dauber, J., Brown, C., Fernando, A.L., Finnan, J., Krasuska, E., Ponitka, J., Styles, D., Thrän, D., Van Groeningen, K. J., Weih, M., and Zah, R.: Bioenergy from "surplus" land: environmental and socio-economic implications, BioRisk, 7, 5-50, https://doi.org/10.3897/biorisk.7.3036, 2012.

Djomo, S. N., Ac, A., Zenone, T., De Groote, T., Bergnate, S., Facciotto, G., Sixto, H., Cira Cira, P., Weger, J., and Ceulemans, R.: Energy performance of intensive and extensive short rotation cropping systems for woody biomass production in the EU, Renew. Sust. Energ. Rev., 41, 845-854, https://doi.org/10.1016/j.rser.2014.08.058, 2015.

EC, European Commission: Directive 2009/28/EC of the European Parliament and of the Council of 23 April 2009 on the promotion of the use of energy from reneable sources and amending and subsequently repealing Directives 2001/77/EC and 2003/30/EC, available at: https://eur-lex.europa. eu/legal-content/EN/ALL/?uri=CELEX:32009L0028 (last access: 3 December 2018), 2009.

EC, European Commission: National Renewable Energy Action Plans in accordance with Directive 2009/28/EC on the promotion of the use of energy from renewable sources, available at: https://ec.europa.eu/energy/en/topics/renewable-energy/ national-action-plans (last access: 3 December 2018), 2010.

EC, European Commission: Regulation No 1305/2013 of the European Parliament and of the Council of 17 December 2013 on support for rural development by the European Agricultural Fund for Rural Development (EAFRD), 2013a.

EC, European Commission: Regulation No 1307/2013 of the European Parliament and of the Council of 17 December 2013 establishing rules for direct payments to farmers under support schemes within the framework of the common agricultural policy and repealing Council Regulation (EC) No 637/2008 and Council Regulation (EC) No 73/2009, 2013 b.

European Forest Genetic Resources Programme (EUFORGEN): available at: http://www.euforgen.org/ (last access: 3 December 2018), 2016.

FAO: Guidelines for soil description, FAO, Rome, Italy, 2006. 
Fernando, A. L., Costa, J., Barbosa, B., Monti, A., and Rettenmaier, N.: Environmental impact assessment of perennial crops cultivation on marginal soils in the Mediterranean Region, Bioass. Bioenerg., 111, 174-186, https://doi.org/10.1016/j.biombioe.2017.04.005, 2018.

Fischer, G., Hizsnyik, E., Prieler, S., Shah, M., and Velthuizen, H.: Biofuels and food security - implication of accelerated biofuels production, Summary of the OFID study prepared by IIASA, Vienna, Austria, 2009.

Fritz, S., See, L., van der Velde, M., Nalepa, R.A., Perger, C., Schill, C., McCallum, I., Schepaschenko, D., Kraxner, F., Cai, X., Zhang, X., Ortner, S., Hazarika, R., Cipriani, A., Di Bella, C., Rabia, A.H., Garcia, A., Vakolyuk, M., Singha, K., Beget, M.E., Erasmi, S., Albrecht, F., Shaw, B., and Obersteiner, M.: Downgrading Recent Estimates of Land Available for Biofuel Production, Environ. Sci. Technol., 47, 1688-1694, https://doi.org/10.1021/es303141h, 2013.

Hangen, E. and Förster, H.: Investigating translated data of the German soil-quality assessment using pinpoint field validation, J. Plant Nutr. Soil Sc., 176, 680-687, https://doi.org/10.1002/jpln.201300021, 2013.

Harrach, T., Kuhn, W., and Zörb, H.: Klassifizierung von Gefügewerten zur Abgrenzung und Beurteilung von Schadverdichtungen nach wurzelökologischen Kriterien, Mitteilungen der Deutschen Bodenkundlichen Gesellschaft, 91, 1217-1220, 1999.

Hennings, V., Höper, H., and Mueller, L.: Small-scale Soil Functional Mapping of Crop Yield Potentials in Germany, in: Novel Methods for Monitoring and Managing Land and Water Resources in Siberia, edited by: Mueller, L., Sheudshen, A. K., and Eulenstein, F., Springer, Germany, 597-617, 2016.

IUSS Working Group WRB: World Reference Base for Soil Resources, World Soil Resources Reports, 103, FAO, Rome, Italy, 2007.

Kang, S., Post, W., Nichols, J., Wang, D., West, T., Bandaru, V., and Izaurralde, R.: Marginal Lands. Concept, Assessment and Management, J. Agr. Sci., 5, 129-139, https://doi.org/10.5539/jas.v5n5p129, 2013.

Kluts, I., Wicke, B., Leemans, R., and Faaij, A.: Sustainability constraints in determining European bioenergy potential: A review of existing studies and steps forward, Rew. Sust. Energ. Rev., 69, 719-734, https://doi.org/10.1016/j.rser.2016.11.036, 2017.

Korakis, G.: Forest botany. Indigenous trees and shrubs of Greece, Athens: Union of Greek Academic Libraries, available at: https:// hdl.handle.net/11419/742 (last access: 3 December 2018), 2015.

Krasuska, E., Cadorniga, C., Tenorio, J., Testa, G., and Scordia, D.: Potential land availability for energy crops production in Europe, Biofuel. Bioprod. Bior., 4, 658-673, https://doi.org/10.1002/bbb.259, 2010.

Lichtfuss, R.: Bodenkundlich-Sensorische Ansprache von Bodenproben, Ein Verfahren zur Beschreibung von Bodenproben, Bodenschutz, 1/04, 21-24, 2004.

Liu, T., Huffmann, T., Kulshreshta, S., McConkey, B., Du, Y., Green, M., Liu, J., Shang, J., and Geng, X.: Bioenergy production on marginal land in Canada: Potential, economic feasibility, and greenhouse gas emissions impacts, Appl. Energ., 205, 477-485, https://doi.org/10.1016/j.apenergy.2017.07.126, 2017.

Miyake, S., Smith, C., Peterson, A., McAlpine, C., Renouf, M., and Waters, D.: Environmental implications of using "underutilised agricultural land" for future bioenergy crop production, Agr.
Syst., 139, 180-195, https://doi.org/10.1016/j.agsy.2015.06.010, 2015.

Mueller, L., Schindler, U., Behrendt, A., Eulenstein, F., and Dannowski, R.: The Muencheberg Soil Quality Rating (SQR) Field Manual for detecting and assessing properties and limitations of soils for cropping and grazing, Müncheberg, Germany, 2007.

Mueller, L., Schindler, U., Mirschel, W., Shepherd, T. G., Ball, B. C., Helming, K., Rogasik, J., Eulenstein, F., and Wiggering, H.: Assessing the productivity function of soils. A review, Agron. Sustain. Dev., 30, 601-614, https://doi.org/10.1051/agro/2009057, 2010.

Mueller, L., Schindler, U., Hennings, V., Smolentseva, E. N., Rukhovich, O. V., Romanenkov, V. A., Sychev, V. G., Lukin, S., Sheudshen, A. K., Onishenko, L., Saparov, A., Pachikin, K., Behrendt, A., Mirschel, W., and Eulenstein, F.: An Emerging Method of Rating Global Soil Quality and Productivity Potentials, in: Novel Methods for Monitoring and Managing Land and Water Resources in Siberia, edited by: Mueller, L., Sheudshen, A. K., and Eulenstein, F., Springer, Heidelberg, 573-595, 2016.

Nalepa, R. A. and Bauer, D. M.: Marginal lands: the role of remote sensing in constructing landscapes for agrofuel development, Jounal of Peasant Studies, 39, 403-422, https://doi.org/10.1080/03066150.2012.665890, 2012.

Panoutsou, C., Singh, A., Uslu, A., van Stralen, J., Kwant, K., Muisers, J., Pelkmans, L., and Devriendt, N.: Lessons and recommendations for EU and national policy frameworks, BiomassPolicies, D4.4, p. 50, 2016.

Plants For A Future (PFAF) Database: Database plant search page, available at: https://www.pfaf.org/user/Default.aspx (last access: 3 December 2018), 2016.

Plieninger, T. and Gaertner, M.: Harnessing degraded lands for biodiversity conservation, J. Nat. Conserv., 19, 18-23, https://doi.org/10.1016/j.jnc.2010.04.001, 2011.

Popp, J., Lakner, Z., Harangi-Rákos, M., and Fári, M.: The effect of bioenergy expansion: Food, energy and environment, Renew. Sust. Energ. Rev., 32, 559-578, https://doi.org/10.1016/j.rser.2014.01.056, 2014.

Rathmann, R., Szklo, A., and Schaeffer, R.: Land use competition for production of food and liquid biofuels: An analysis of the arguments in the current debate, Renew. Energ., 35, 14-22, https://doi.org/10.1016/j.renene.2009.02.025, 2010.

San-Miguel-Ayanz, J., de Rigo, D., Caudullo, G., Houston Durrant, T., and Mauri, A. (Eds.): European Atlas of Forest Tree Species, Publication Office of the European Union, Luxembourg, 2016.

Scarlat, N., Dallemand, J.-F., Monforti-Ferrario, F., Banja, M., and Motola, V.: Renewable energy policy framework and bioenergy contribution in the European Union - An overview from National Renewable Energy Action Plans and Progress Reports, Renew. Sust. Energ. Rev., 51, 969-985, 2015.

Shepherd, T. G.: Visual Soil Assessment, Volume 1. Field guide for cropping and pastoral grazing on flat to rolling country, horizons.mw \& Landcare Research, Palmerston North, 2000.

Shortall, O.: Marginal land for energy crops. Exploring definitions and embedded assumptions, Energ. Policy, 62, 19-27, https://doi.org/10.1016/j.enpol.2013.07.048, 2013.

Śliż-Szkliniarz, B.: Energy Planning in Selected European Regions: Methods for Evaluating the Potential of Renewable Energy Sources, KIT Scientific Publishing, Karlsruhe, 2013. 
Strijker, D.: Marginal lands in Europe - causes of decline, Basic Appl. Ecol., 6, 99-106, https://doi.org/10.1016/j.baae.2005.01.001, 2005.

United States Department of Agriculture (USDA): Plants database, available at: https://plants.usda.gov/java/ (last access: 3 December 2018), 2016.

van Orshoven, J., Terres, J., and Tóth, T.: Updated common biophysical criteria to define natural constraints for agriculture in Europe Luxembourg. Publications Office of the European Union, 2014.
Wolf, J., Bindraban, P., Luijten, J., and Vleeshouwers, L.: Exploratory study on the land area required for global food supply and the potential global production of bioenergy, Agr. Syst., 76, 841-861, https://doi.org/10.1016/S0308-521X(02)00077-X, 2003. 